\title{
A live cell NanoBRET binding assay allows the study of ligand-binding kinetics to the adenosine $A_{3}$ receptor
}

\author{
Monica Bouzo-Lorenzo ${ }^{1,2} \cdot$ Leigh A. Stoddart ${ }^{1,2} \cdot$ Lizi Xia $^{3}$ - Adriaan P. IJzerman ${ }^{3}$ - Laura H. Heitman ${ }^{3}$. \\ Stephen J. Briddon ${ }^{1,2} \cdot$ Stephen J. Hill ${ }^{1,2}$ (D)
}

Received: 25 November 2018 / Accepted: 14 February 2019 / Published online: 27 March 2019

(C) The Author(s) 2019

\begin{abstract}
There is a growing interest in understanding the binding kinetics of compounds that bind to G protein-coupled receptors prior to progressing a lead compound into clinical trials. The widely expressed adenosine $A_{3}$ receptor $\left(A_{3} A R\right)$ has been implicated in a range of diseases including immune conditions, and compounds that aim to selectively target this receptor are currently under development for arthritis. Kinetic studies at the $\mathrm{A}_{3} \mathrm{AR}$ have been performed using a radiolabelled antagonist, but due to the kinetics of this probe, they have been carried out at $10^{\circ} \mathrm{C}$ in membrane preparations. In this study, we have developed a live cell NanoBRET ligand binding assay using fluorescent $A_{3} A R$ antagonists to measure kinetic parameters of labelled and unlabelled compounds at the $\mathrm{A}_{3} \mathrm{AR}$ at physiological temperatures. The kinetic profiles of four fluorescent antagonists were determined in kinetic association assays, and it was found that XAC-ser-tyr-X-BY630 had the longest residence time $(\mathrm{RT}=288 \pm 62 \mathrm{~min})$ at the $\mathrm{A}_{3} \mathrm{AR}$. The association and dissociation rate constants of three antagonists PSB-11, compound 5, and LUF7565 were also determined using two fluorescent ligands (XAC-sertyr-X-BY630 or AV039, RT $=6.8 \pm 0.8 \mathrm{~min}$ ) as the labelled probe and compared to those obtained using a radiolabelled antagonist ([ $\left.\left.{ }^{3} \mathrm{H}\right] \mathrm{PSB}-11, \mathrm{RT}=44.6 \pm 3.9 \mathrm{~min}\right)$. There was close agreement in the kinetic parameters measured with AV039 and $\left[{ }^{3} \mathrm{H}\right] \mathrm{PSB}-11$ but significant differences to those obtained using XAC-S-ser-S-tyr-X-BY630. These data indicate that selecting a probe with the appropriate kinetics is important to accurately determine the kinetics of unlabelled ligands with markedly different kinetic profiles.
\end{abstract}

Keywords Adenosine $\mathrm{A}_{3}$ receptor $\cdot$ Binding kinetics $\cdot$ Residence time $\cdot$ NanoBRET

\section{Introduction}

The nucleoside adenosine is a ubiquitous signalling molecule which modulates cellular responses to stress. Upon cellular stress caused by mechanical, inflammatory or hypoxic stressors, high concentrations of ATP are released [1,2] which

Monica Bouzo-Lorenzo and Leigh A. Stoddart contributed equally to this work.

Stephen J. Hill

steve.hill@nottingham.ac.uk

1 Cell Signalling and Pharmacology Research Group, Division of Physiology, Pharmacology and Neuroscience, School of Life Sciences, University of Nottingham, Nottingham, UK

2 Centre of Membrane Proteins and Receptors (COMPARE), University of Birmingham and University of Nottingham, Midlands, UK

3 Division of Drug Discovery and Safety, Leiden Academic Centre for Drug Research, Leiden University, 9502, 2300

RA Leiden, The Netherlands are rapidly hydrolysed to adenosine [3]. Adenosine signals via four related family A G protein-coupled receptors (GPCRs) [4] of which the adenosine $A_{3}$ receptor $\left(A_{3} A R\right)$ is thought to play an important role in the control of infection and related inflammation due to its expression on immune cells [5]. It has also been proposed to play a cardio- $[6,7]$ and neuroprotective $[8,9]$ role. In addition, the $\mathrm{A}_{3} \mathrm{AR}$ receptor has been shown to be expressed in a variety of cancer cell lines, and since the tumour micro-environment is often hypoxic, it may play a role in tumour progression [10]. This has led to an interest in developing molecules that target the $\mathrm{A}_{3} \mathrm{AR}$ in the treatment of immune conditions and cancer [11].

In recent years, many molecules targeting GPCRs, including those acting at adenosine receptors [12], have exhibited a lack of efficacy in clinical trials [13]. The optimization of molecules for clinical trials has historically focused on developing a candidate with high affinity and selectivity for the target receptor, and these parameters are often measured at equilibrium in model cell systems over-expressing the receptor of interest $[14,15]$. Within the last 10 years, it has become clear that measuring the binding properties of a molecule at 
equilibrium may not be the most effective way to determine potential in vivo efficacy and that determining the duration of protein-drug interactions may be a better predictor of in vivo action $[16,17]$. As the equilibrium dissociation constant $\left(K_{\mathrm{d}}\right)$ of a ligand at a GPCR is a function of the ligand's association $\left(k_{\text {on }}\right)$ and dissociation rate $\left(k_{\text {off }}\right)$ constants $\left(K_{\mathrm{d}}=k_{\text {off }} / k_{\text {on }}\right)$, molecules that have the same measured $K_{\mathrm{D}}$ at equilibrium can have markedly different $k_{\text {on }}$ and $k_{\text {off }}$ rate constants. To address this, Copeland et al. (2006) introduced the concept residence time (RT), which is the reciprocal of the dissociation rate constant $\left(\mathrm{RT}=1 / k_{\mathrm{off}}\right)$, as a measure of the duration of drugtarget complex formation [18]. Depending on the clinical setting, different RTs may be required. For example, drugs with a long RT are preferred when an extended duration of action is required and can reduce administration to once a day. This has been demonstrated for the M3 muscarinic receptor antagonist tiotropium and the $\beta_{2}$ adrenoceptor agonist olodaterol which both have long RTs and are once a day bronchodilators used to treat chronic obstructive pulmonary disease $[14,19,20]$. Short RT ligands are advantageous when the rapid, i.e. seconds to minutes, replacement of the drug by an endogenous ligand is crucial to avoid long-term side effects which has been proposed to be the case for drugs targeting the dopamine $\mathrm{D}_{2}$ receptor [17, 21, 22].

A variety of techniques exist to measure the kinetic parameters of molecules binding to the protein target of interest. As GPCRs are integral membrane proteins, biophysical techniques such as surface plasmon resonance which require purified protein can be challenging and often require mutagenesis to stabilise the receptor and allow it to be purified within lipid micelles or nanodiscs $[23,24]$. Techniques that do not require the receptor to be purified include those that use radiolabelled or fluorescently labelled ligands $[25,26]$. One limitation of these techniques is that they can only directly measure the kinetic parameters of the labelled compound. To overcome this, the methodology proposed by Motulsky and Mahan is often employed [27]. This technique measures the association kinetics of a labelled ligand in the presence of an unlabelled ligand and through knowledge of the kinetic parameters of the labelled ligand both the association and dissociation rate constants of the unlabelled ligand can be calculated. This technique is widely used with radiolabelled ligands and has more recently been successfully applied in combination with fluorescently labelled ligands in resonance energy transfer techniques such as time-resolved resonance energy transfer (TR-FRET) and bioluminescence resonance energy transfer (BRET) $[28,29]$.

For the $\mathrm{A}_{3} \mathrm{AR}$, two recent studies have used radioligands to determine the kinetic parameters of unlabelled ligands [30, 31]. In the study by Xia et al., however, the radiolabelled antagonist $\left(\left[{ }^{3} \mathrm{H}\right] \mathrm{PSB}-11\right)$ had to be used at low temperatures $\left(10^{\circ} \mathrm{C}\right)$ to slow the association rate sufficiently to give enough resolution to accurately determine the kinetic binding parameters of unlabelled ligands [30]. Due to this limitation and the inherent issue of throughput associated with radioligands [25], there is a need to develop additional methods to measure kinetic parameters. One way to potentially overcome these issues is through the use of fluorescently labelled ligand which have increased throughput, and previous studies have suggested that the fluorescent $A_{3} A R$ antagonist CA200645 has a slower association rate than $\left[{ }^{3} \mathrm{H}\right] \mathrm{PSB}$ 11 [32]. For the $A_{3} A R$, a number of fluorescently labelled antagonist probes have been developed based on two structurally distinct antagonists which have been shown to retain high affinity for the receptor [32-34]. Therefore, in this study, we have developed a live-cell BRET-based kinetic binding assay for the $\mathrm{A}_{3} \mathrm{AR}$ using four different fluorescently labelled antagonists. This assay has then been compared to the radioligand binding assay described in Xia et al. [30] for the determination of the kinetic binding parameters of unlabelled ligands.

\section{Material and methods}

\section{Materials}

Foetal calf serum (FCS) was obtained from PAA Laboratories (Wokingham, UK). Furimazine was purchased from Promega (Southampton, UK). Bicinchoninic acid protein assay kit and white 96-well microplates were obtained from Thermo Fisher Scientific (Waltham, MA, USA). GF/B filter plates and Microscint-O were from PerkinElmer (Groningen, The Netherlands). CA200645 was obtained from HelloBio (Bristol, UK). The synthesis of AV039 was described in Vernall et al. as compound 19 [34], while the synthesis of $\mathrm{XAC}-S$-ser-S-tyr-X-BY630 (compound 27) and XAC-S-ser$S$-tyr-X-BYFL (compound 28) was described in Vernall et al. 2013 [33]. PSB-11 and MRS1220 were purchased from Tocris Bioscience (Bristol, UK), and NECA was obtained from Sigma-Aldrich (Zwijndrecht, The Netherlands). $\left[{ }^{3} \mathrm{H}\right] 8$ Ethyl-4-methyl-2-phenyl-(8R)-4,5,7,8-tetrahydro- $1 \mathrm{H}$ imidazo[2,1-i]-purin-5-one $\left(\left[{ }^{3} \mathrm{H}\right] \mathrm{PSB}-11\right)$ was kindly donated by Prof. C.E. Müller (University of Bonn, Germany) and its synthesis described in Müller et al. [35]. 1-Benzyl-8-methoxy1H,3H-pyrido[2,1-f]purine-2,4-dione (compound 5) synthesis was described in Priego et al. as compound number 3 [36] and referred in Xia et al. [37] as compound number 5, while LUF7565 synthesis was described in Xia et al. as compound 27 [30]. All other chemicals and reagents were obtained from Sigma-Aldrich (Gillingham, UK).

\section{Cell culture and membrane preparation}

Generation of human embryonic kidney 293 (HEK293) cells stably expressing the human $\mathrm{A}_{3} \mathrm{AR}$ tagged at the $\mathrm{N}$-terminus 
with NanoLuc (Nluc- $A_{3} A R$ ) is described in Stoddart et al. [38], and these cells were used throughout this study. NlucA 3 AR HEK293 cells were maintained in Dulbecco's modified Eagle's medium containing $10 \% \mathrm{FCS}$ and $2 \mathrm{mM}$ L-glutamine at $37^{\circ} \mathrm{C}, 5 \% \mathrm{CO}_{2}$.

For membrane preparation, Nluc-A AR HEK293 cells were grown to confluence in $500-\mathrm{cm}^{2}$ dishes. Normal growth media was replaced with ice-cold PBS, and the cells were removed from the dish using a cell scraper. The cells were then transferred to a $50-\mathrm{ml}$ tube and centrifuged at $250 \times \mathrm{g}$ for $5 \mathrm{~min}$. The supernatant was discarded, and the resulting pellets were stored at $-80^{\circ} \mathrm{C}$. Thawed pellets were resuspended in ice-cold PBS and homogenised using an IKA T10 UltraTurrax disperser in $10 \times 5 \mathrm{~s}$ bursts at $15,000 \mathrm{rpm}$. After removal of unbroken cells and nuclei by centrifugation at $1200 \times g$ for $10 \mathrm{~min}$, the supernatant was centrifuged at $41,415 \times g$ for $30 \mathrm{~min}$ to obtain the membrane pellet. The pellet was then resuspended in ice-cold PBS and homogenised by 20 passes using a Kartell serrated pestle and a borosilicate glass homogeniser mortar fitted to an IKA RW16 overhead stirrer set to $1000 \mathrm{rpm}$. Finally, protein concentration was determined using a bicinchoninic acid protein assay [37] and membranes stored at $-80{ }^{\circ} \mathrm{C}$ until needed.

\section{NanoBRET binding assays}

HEK293 cells stably expressing human Nluc- $\mathrm{A}_{3}$ AR were seeded in normal growth medium $24 \mathrm{~h}$ prior to experimentation in white 96-well microplates coated with poly-D-lysine $(100 \mu \mathrm{g} / \mathrm{ml}$ poly-D-lysine in PBS, $30 \mathrm{~min}$ room temperature, then washed in normal growth medium prior to use). Immediately before experimentation, media was replaced with HEPES buffered saline solution (HBSS; $145 \mathrm{mmol} / \mathrm{L}$ $\mathrm{NaCL}, 5 \mathrm{mmol} / \mathrm{L} \mathrm{KCl}, 1.7 \mathrm{mmol} / \mathrm{L} \mathrm{CaCl} 2,1 \mathrm{mmol} / \mathrm{L}$ $\mathrm{MgSO}_{4}, 10 \mathrm{mmol} / \mathrm{L}$ HEPES, $2 \mathrm{mmol} / \mathrm{L}$ sodium pyruvate,

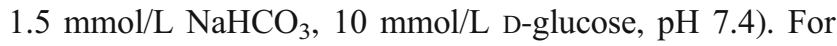
saturation and competition binding assays, the required concentration of fluorescent ligand and competing ligand was added simultaneously and incubated for $1 \mathrm{~h}$ (for AV039) or $3 \mathrm{~h}$ (for XAC-S-ser-S-tyr-X-BY630) at $37^{\circ} \mathrm{C}\left(\right.$ no $\mathrm{CO}_{2}$ ). After $1 \mathrm{~h}, 10 \mu \mathrm{M}$ furimazine was added to each well and the plate incubated for $5 \mathrm{~min}$ at $37^{\circ} \mathrm{C}$ before reading. Prior to all kinetic experiments, the medium was replaced by HBSS containing $10 \mu \mathrm{M}$ furimazine and incubated at room temperature in the dark for $15 \mathrm{~min}$ to allow the luminescence signal to reach equilibrium [29]. For association kinetic experiments, following the furimazine incubation, the required concentration of fluorescent ligand in the presence or absence of $10 \mu \mathrm{M}$ MRS1220 was added simultaneously and the plate read immediately once per minute for up to $3 \mathrm{~h}$ at $37{ }^{\circ} \mathrm{C}$. For kinetic competition association assays, after furimazine incubation, either XAC-S-ser-S-tyr-X-BY630 (20 nM) or AV039 $(40 \mathrm{nM})$ were added simultaneously with the required concentration of unlabelled ligand or $10 \mu \mathrm{M}$ MRS1220 to determine non-specific binding and read once per minute for the indicated times at $37^{\circ} \mathrm{C}$. For all NanoBRET experiments, fluorescence and luminescence were read using a PHERAstar FS plate reader (BMG Labtech, Ortenberg, Germany). Filtered light emissions were measured at $460 \mathrm{~nm}(80 \mathrm{~nm}$ band pass) and at $>610 \mathrm{~nm}$ (long pass) for the BY630 labelled ligands and at $450 \mathrm{~nm}$ ( $80 \mathrm{~nm}$ band pass) and $>550 \mathrm{~nm}$ (long pass) for the BYFL labelled ligand. The raw NanoBRET ratio was calculated by dividing the fluorescence emission ( 610 or $550 \mathrm{~nm}$ ) by the luminescence emission (460 or $450 \mathrm{~nm}$ ).

\section{Radioligand binding assays}

Prior to all experiments, membranes from HEK 293 membranes expressing human Nluc- $\mathrm{A}_{3} \mathrm{AR}$ were diluted to $20 \mu \mathrm{g} / \mathrm{well}$ in a total volume of $100 \mu \mathrm{L} /$ well assay buffer $\left(50 \mathrm{mM}\right.$ Tris- $\mathrm{HCl}, 5 \mathrm{mM} \mathrm{MgCl}{ }_{2}$, supplemented with $0.01 \%$ CHAPS and $1 \mathrm{mM}$ EDTA, $\mathrm{pH}$ 7.4) and homogenised using an IKA T10 Ultra-Turrax disperser in $3 \times 5 \mathrm{~s}$ bursts at $15,000 \mathrm{rpm}$. For equilibrium displacement assays, membranes were placed in 96-well microplates at $10{ }^{\circ} \mathrm{C}$ and the required concentration of competing agonist was added in the presence of a final concentration of $\sim 10 \mathrm{nM}\left[{ }^{3} \mathrm{H}\right]$ PSB-11 with nonspecific binding determined in the presence of $100 \mu \mathrm{M}$ NECA (final concentration). For association assays, Nluc- $\mathrm{A}_{3} \mathrm{AR}$ HEK293 membranes were placed at $10{ }^{\circ} \mathrm{C}$ in 96 -well microplates and the amount of radioligand bound to the receptor was measured at different time points during a total incubation of $120 \mathrm{~min}$. For dissociation experiments, HEK293 membranes expressing human Nluc$\mathrm{A}_{3} \mathrm{AR}$ were incubated for $120 \mathrm{~min}$ with $\sim 10 \mathrm{nM}\left[{ }^{3} \mathrm{H}\right]$ PSB-11 at $10{ }^{\circ} \mathrm{C}$ prior the addition of $10 \mu \mathrm{M}$ PSB-11 (final concentration) at various time points during a further $120 \mathrm{~min}$. The competition association assays were initiated by the addition of Nluc-A AR HEK293 membranes at different time points for a total of $240 \mathrm{~min}$ to a total volume of $100 \mu \mathrm{l} /$ well of assay buffer at $10{ }^{\circ} \mathrm{C}$ with $\sim 10 \mathrm{nM}\left[{ }^{3} \mathrm{H}\right]$ PSB-11 in the absence or presence of a single concentration $\left(2 \times K_{\mathrm{i}}\right)$ of competing $\mathrm{A}_{3} \mathrm{AR}$ ligands. For all experiments, incubation was terminated by rapid filtration performed on 96-well GF/B filter plates using a PerkinElmer Filtermate-harvester (PerkinElmer, Groningen, The Netherlands). After drying the filter plate at $50{ }^{\circ} \mathrm{C}$ for $30 \mathrm{~min}$, the filter-bound radioactivity was determined by scintillation spectrometry using a 2450 MicroBeta $^{2}$ Plate Counter (PerkinElmer, Boston, MA). In addition, the exact concentration of $\left[{ }^{3} \mathrm{H}\right]$ PSB-11 used in each experiment was determined by scintillation spectrometry and this concentration was used in the data analysis. 


\section{Data analysis}

All experimental data were analysed using Prism7 (GraphPad Software, San Diego, CA).

NanoBRET total and non-specific saturation binding curves were fitted simultaneously using the following equation:

BRET ratio $=\frac{B_{\max } \cdot[B]}{[B]+K_{\mathrm{D}}}+((M \cdot[B])+C)$

where $B_{\max }$ is the maximal specific binding achieved, $[B]$ is the concentration of fluorescent ligand, $K_{\mathrm{D}}$ is the equilibrium dissociation constant, $M$ is the slope of the non-specific binding component and $C$ is the intercept with the $Y$-axis.

Equilibrium competition binding curves were fitted with the following equation:

$$
K_{\mathrm{i}}=\frac{\mathrm{IC}_{50}}{1+\frac{[L]}{K_{\mathrm{D}}}}
$$

where $[L]$ is the concentration of $\left[{ }^{3} \mathrm{H}\right] \mathrm{PSB} 11, \mathrm{AV} 039$ or XAC$S$-ser- $S$-tyr-X-BY630 and $K_{\mathrm{D}}$ is the equilibrium dissociation constant of the labelled ligand $\left(9.9 \mathrm{nM}\right.$ for $\left[{ }^{3} \mathrm{H}\right] \mathrm{PSB}-11$, $14.5 \mathrm{nM}$ for XAC- $S$-ser- $S$-tyr-X-BY630 and $32.5 \mathrm{nM}$ for AV039 as determined in saturation binding assay performed as part of this study). The $\mathrm{IC}_{50}$ is obtained as follows:

\%inhibition of specific binding $=\frac{100 \cdot[A]}{[A]+\mathrm{IC}_{50}}$

where $[A]$ is the concentration of unlabelled competing drug and $\mathrm{IC}_{50}$ is the molar concentration of this competing ligand required to inhibit $50 \%$ of the specific binding of the concentration $[L]$ of the labelled ligand.

For NanoBRET association kinetic data, non-specific binding was determined in wells with fluorescent ligand plus $10 \mu \mathrm{M}$ MRS1220 and this was obtained for each concentration of fluorescent ligand at each time point. This was subsequently subtracted from total binding at the equivalent time point. The data were simultaneously fit to the following equations:

$Y=Y_{\max }\left(1-e^{-k_{\mathrm{obs}} t}\right)$

$k_{\mathrm{on}}=\frac{k_{\mathrm{obs}}-k_{\mathrm{off}}}{[L]}$

where $Y_{\max }$ equals the level of binding at infinite time $(t), k_{\mathrm{obs}}$ is the rate constant for the observed rate of association at a particular concentration of $L,[L]$ is the ligand concentration in molar, $k_{\text {off }}$ is the dissociation rate constant of the ligand in per minute and $k_{\mathrm{on}}$ is the association rate constant in per molar per minute. From this, the equilibrium dissociation constant $\left(\mathrm{K}_{\mathrm{D}}\right)$ is determined as follows:

$$
K_{\mathrm{D}}=\frac{k_{\mathrm{off}}}{k_{\mathrm{on}}}
$$

The binding kinetics of unlabelled ligands was quantified using the competition association assay based on the theoretical framework by Motulsky and Mahan [27]. NanoBRET and radioligand data were fitted into the competition association model using 'kinetics of competitive binding' to determine association and dissociation rate constants of the unlabelled compounds:

$$
\begin{gathered}
K_{A}=k_{1}[L] \cdot 10^{-9}+k_{2} \\
K_{B}=k_{3}[I] \cdot 10^{-9}+k_{4} \\
S=\sqrt{\left(K_{A}-K_{B}\right)^{2}+4 \cdot k_{1} \cdot k_{3} \cdot L \cdot I \cdot 10^{-18}} \\
K_{F}=0.5\left(K_{A}+K_{B}+S\right) \\
K_{S}=0.5\left(K_{A}+K_{B}-S\right) \\
Q=\frac{B_{\max } \cdot k_{1} \cdot L \cdot 10^{-9}}{K_{F}-K_{S}} \\
Y=Q \cdot \frac{k_{4} \cdot\left(K_{F}-K_{S}\right)}{K_{F} \cdot K_{S}}+\frac{k_{4}-K_{F}}{K_{F}} e^{\left(-K_{F} \cdot X\right)}-\frac{k_{4}-K_{S}}{K_{S}} e^{\left(-K_{S} \cdot X\right)}
\end{gathered}
$$

where $k_{1}$ is the $k_{\text {on }}$ of the labelled ligand $\left(\mathrm{M}^{-1} \min ^{-1}\right), k_{2}$ is the $k_{\text {off }}$ of the labelled ligand $\left(\mathrm{min}^{-1}\right), L$ is the concentration of the labelled ligand in nanomolar, $I$ is the concentration of the unlabelled competitor (nM), $X$ is the time ( $\mathrm{min})$ and $Y$ is the specific binding of the labelled ligand (NanoBRET ratio or DPM).

$k_{1}$ and $k_{2}$ values were generated from association kinetic experiments. $k_{3}, k_{4}$ and $B_{\max }$ were then calculated, where $k_{3}$ represents the $k_{\text {on }}\left(\mathrm{M}^{-1} \min ^{-1}\right)$ of the unlabelled ligand, $k_{4}$ stands for the $k_{\mathrm{off}}\left(\mathrm{min}^{-1}\right)$ of the unlabelled ligand and $B_{\max }$ equals the total binding (NanoBRET ratio or DPM). The residence time (RT) was calculated as the reciprocal of the ligand dissociation rate constant as follows:

$\mathrm{RT}=\frac{1}{k_{\mathrm{off}}}$

Statistical significance was determined by Student's unpaired $t$ test where $p<0.05$ was considered statistically significant throughout this study.

\section{Results}

\section{NanoBRET binding profile of fluorescent probes at Nluc- $A_{3} A R$ in live cells}

The four fluorescent ligands used in this study have previously been shown to display high affinity for the $A_{3} A R$, and their structures are shown in Fig. 1 [32-34]. Three of the ligands are based on the non-selective adenosine receptor antagonist 
xanthine amine congener (XAC). Two of these XAC linked compounds contain a serine, tyrosine dipeptide (both in the $S$ configuration) to link the pharmacophore to the fluorophore which is either BODIPY630/650 (excitation max $630 \mathrm{~nm}$, emission max $650 \mathrm{~nm}$ ) to give XAC-S-ser-S-tyr-BY630 (Fig. 1a, or BODIPY-FL (excitation max $503 \mathrm{~nm}$, emission $\max 512 \mathrm{~nm}$ ) to give XAC-S-ser-S-tyr-BYFL (Fig. 1b) [33]. The third XACbased compound, CA200645 (Fig. 1c), contains a polyamide linker $(\beta$-alanine, $\beta$-alanine) connected to the BY630 fluorophore [32]. AV039 (Fig. 1d) is based on the $\mathrm{A}_{3} \mathrm{AR}$ selective antagonist 1,2,4-triazolo[4,3-a]quinoxalin-1-one linked to BY630 and has been shown to retain $\mathrm{A}_{3} \mathrm{AR}$ selectivity [34].
Initially, we determined the affinity of each of these fluorescent antagonists at NanoLuc tagged $\mathrm{A}_{3} \mathrm{AR}$ (Nluc- $\mathrm{A}_{3} \mathrm{AR}$ ) in the NanoBRET assay. An advantage of NanoBRET compared to radioligand binding experiments is the large concentration range of fluorescent ligands over which binding can be measured, and to represent this accurately, binding is fitted as a sigmoidal curve with BRET ratio values plotted versus the log concentration of fluorescent ligand. In all the cases, we obtained a saturable curve clearly dependent on the concentration of the fluorescent ligands (Fig. 2). Non-specific binding was determined by co-incubation with $10 \mu \mathrm{M}$ of the unlabelled high affinity $\mathrm{A}_{3} \mathrm{AR}$ antagonist MRS1220, and all four fluorescent a<smiles>CCCn1c(=O)c2[nH]c(-c3ccc(OCC(N)=O)cc3)nc2n(CC)c1=O</smiles>

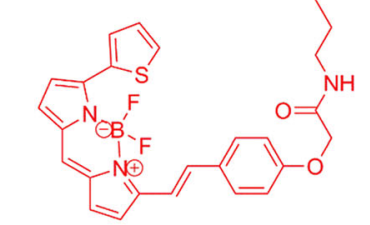

b

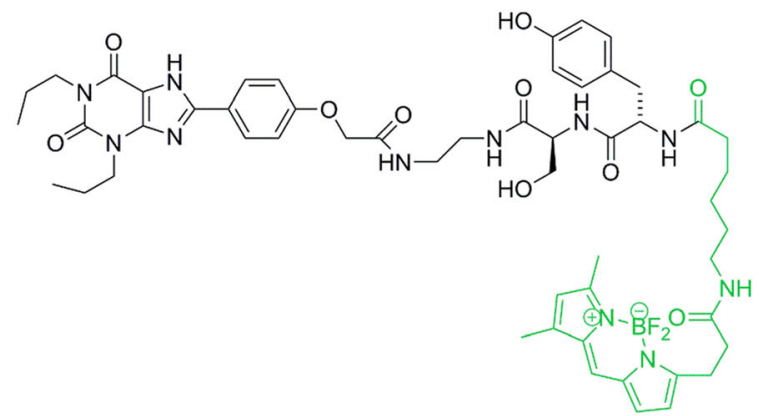

\section{XAC-S-ser-S-tyr-X-BY630}

\section{C}

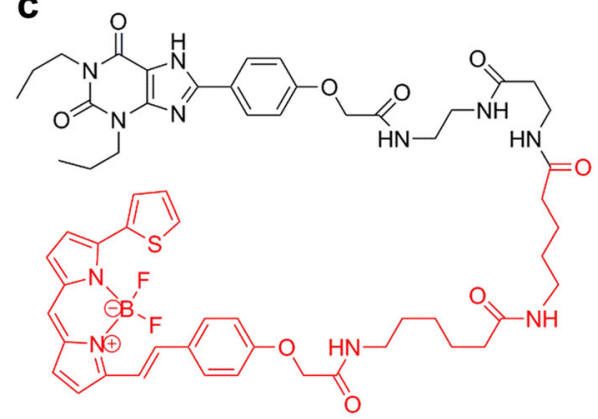

\section{XAC-S-ser-S-tyr-X-BYFL}

d

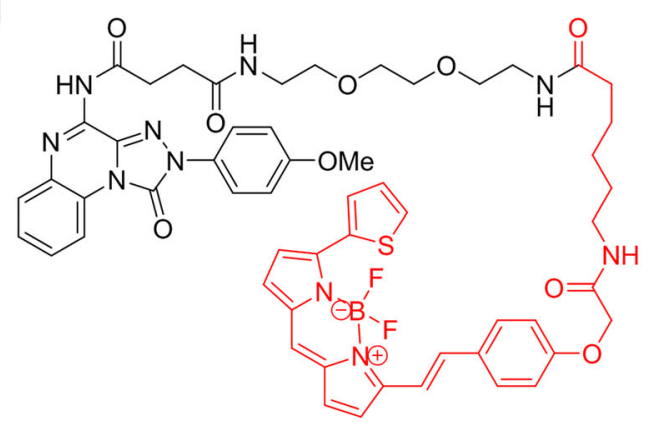

AV039

g<smiles>COc1cccc(Cn2c(=O)n(CC3CC3)c(=O)c3c2nc2cc(OC)ccn23)c1</smiles>

LUF7565<smiles>CC[C@H]1CN2C(=O)N(C)c3nc(-c4ccccc4)[nH]c3C2=N1</smiles>

PSB11

Fig. 1 Structures of the $\mathrm{A}_{3} \mathrm{AR}$ fluorescent (a-d) and unlabelled (e-g) antagonists used in this study 
Fig. 2 Determination of the binding affinity of four fluorescent antagonists at human $\mathrm{A}_{3} \mathrm{AR}$. NanoBRET saturation binding curves obtained by treating Nluc-A 3 AR HEK293 cells with increasing concentrations of the fluorescent antagonists AV039 (a), CA200645 (b), XAC-S-ser-S-tyr$\mathrm{X}$-BYFL (c) or XAC-S-ser-S-tyr$\mathrm{X}$-BY630 (d) in the absence (black circles) or presence (red squares) of $10 \mu \mathrm{M}$ MRS1220 for $1 \mathrm{~h}$ at $37^{\circ} \mathrm{C}$. The data shown are mean \pm SEM and are representative of five independent experiments each performed in triplicate
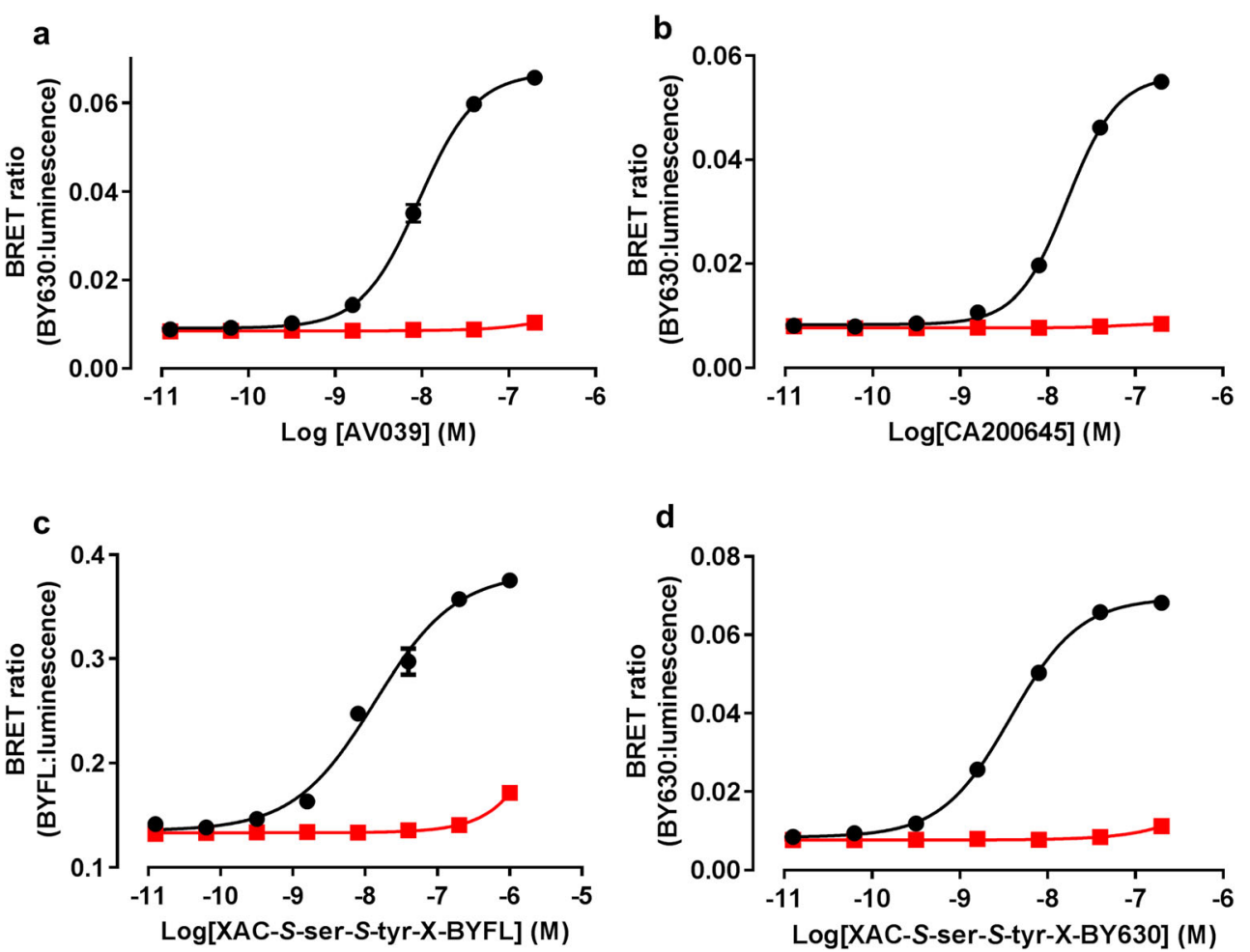

d

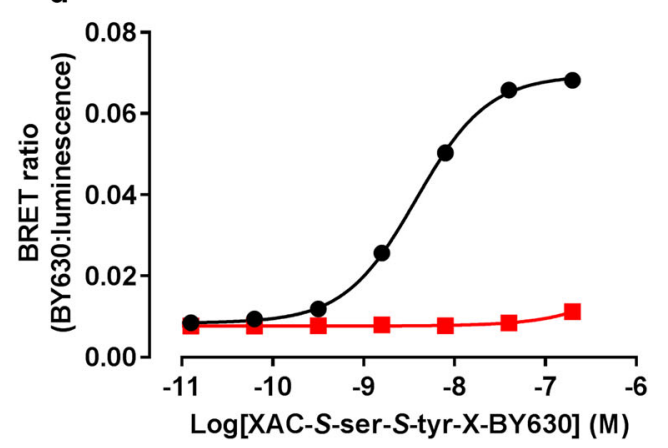

ligands exhibited very low levels of non-specific NanoBRET in line with previously published NanoBRET data [29, 38]. The point on the curve which gives the $50 \%$ of the binding was then taken as $K_{\mathrm{D}}$. The $\mathrm{pK}$ D values calculated for the four fluorescent antagonists are shown in Table 1. All four ligands displayed high affinities for Nluc- $\mathrm{A}_{3} \mathrm{AR}$ which were consistent with literature values, and the range of $\mathrm{pK}_{\mathrm{D}}$ values were found to span less than $1 \log$ unit $\left(\mathrm{pK}_{\mathrm{D}} 7.78-8.11\right)$.

To determine the kinetic parameters of fluorescent ligands at the $\mathrm{A}_{3} \mathrm{AR}$, Nluc- $\mathrm{A}_{3} \mathrm{AR}$ expressing HEK293 cells were initially treated with the Nanoluc substrate, furimazine $(10 \mu \mathrm{M})$, for $15 \mathrm{~min}$ prior to the fluorescent ligand to allow the luminescence signal to stabilise as described previously [29]. Increasing concentrations of fluorescent ligands were then added and the change in NanoBRET monitored at $37^{\circ} \mathrm{C}$ over time, with specific binding determined in the presence of the high affinity $\mathrm{A}_{3} \mathrm{AR}$ antagonist MRS1220 $(10 \mu \mathrm{M})$ for every time point (Fig. 3). The kinetic parameters obtained from globally fitting the association curves showed that all four fluorescent ligands had similar association rates within a factor of two of each other (Table 1). As expected, the range of dissociation rates for AV039, CA200645 and XAC-S-ser- $S$ tyr-X-BYFL were also within a factor of two of each other, leading to similar RTs. The dissociation rate for XAC-S-ser- $S$ tyr-X-BY630, however, was over ten times slower than that of the other three fluorescent ligands. This produced a markedly different RT for XAC-S-ser-S-tyr-X-BY630 which was of the order of hours $(4.8 \mathrm{~h})$ compared to the much more rapid values

Table 1 Kinetic parameters and binding affinities of fluorescent antagonists at the human $\mathrm{A}_{3} \mathrm{AR}$ measured by NanoBRET

\begin{tabular}{|c|c|c|c|c|c|c|c|}
\hline \multirow[b]{2}{*}{ Compound } & \multicolumn{5}{|l|}{ Kinetics } & \multicolumn{2}{|c|}{ Equilibrium saturation } \\
\hline & $\mathrm{pK}_{\mathrm{D}}$ & $k_{\mathrm{on}}\left(\times 10^{6}\right)\left(\mathrm{M}^{-1} \min ^{-1}\right)$ & $k_{\text {off }}\left(\min ^{-1}\right)$ & $\mathrm{RT}(\min )$ & $n$ & $\mathrm{pK}_{\mathrm{D}}$ & $n$ \\
\hline AV039 & $7.35 \pm 0.10^{*}$ & $3.67 \pm 0.62$ & $0.15 \pm 0.02$ & $6.8 \pm 0.8$ & 4 & $8.11 \pm 0.10^{*}$ & 5 \\
\hline CA200645 & $7.58 \pm 0.04^{*}$ & $2.58 \pm 0.05$ & $0.069 \pm 0.006$ & $14.8 \pm 1.1$ & 5 & $7.80 \pm 0.07 *$ & 5 \\
\hline XAC-S-ser-S-tyr-X-BY630 & $8.57 \pm 0.15$ & $1.66 \pm 0.36$ & $0.0043 \pm 0.0009$ & $288 \pm 62$ & 5 & $8.51 \pm 0.07$ & 5 \\
\hline XAC-S-ser-S-tyr-X-BYFL & $7.75 \pm 0.14$ & $3.95 \pm 0.73$ & $0.069 \pm 0.006$ & $14.9 \pm 1.1$ & 4 & $7.78 \pm 0.05$ & 5 \\
\hline
\end{tabular}

Saturation $\mathrm{pK}_{\mathrm{D}}$ values were calculated directly from the saturation binding curves of the fluorescent ligands binding to Nluc- $\mathrm{A}_{3} \mathrm{AR}$ HEK293 cells. The kinetic parameters, $k_{\mathrm{on}}, k_{\mathrm{off}}$ and $\mathrm{pK}$ D values, were obtained by monitoring the NanoBRET signal over time of various concentrations of fluorescent ligand in HEK293 Nluc-A $\mathrm{A}_{3}$ AR cells at $37^{\circ} \mathrm{C}$. The residence time (RT) was calculated as the reciprocal of the $k_{\text {off }}$ values from each individual experiment. All values represent mean \pm SEM from $n$ separate experiments performed in triplicate

${ }^{*} p<0.05$, kinetic versus equilibrium saturation $\mathrm{pK}_{\mathrm{D}}$ values according to unpaired Student's $t$ test 

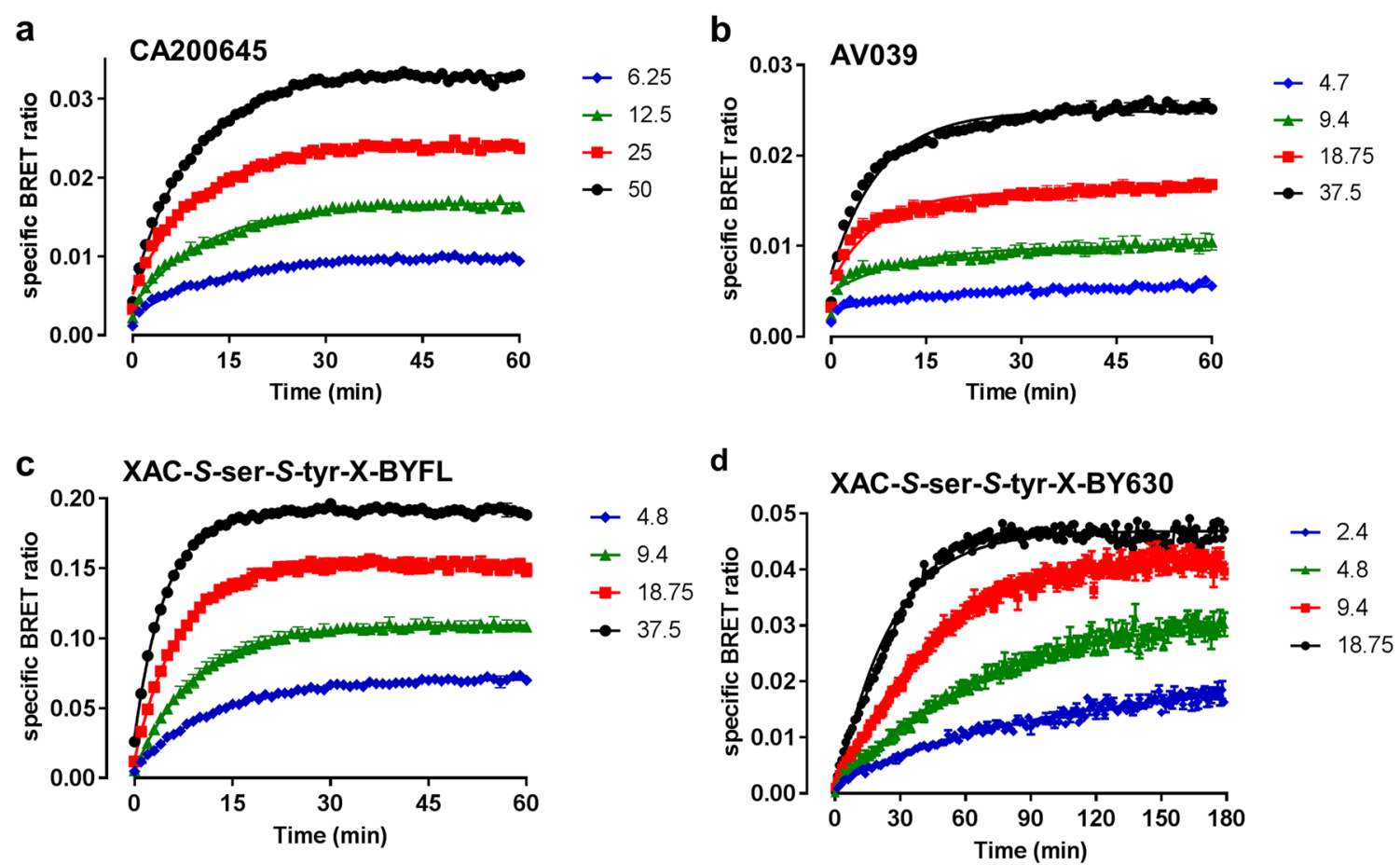

Fig. 3 Association kinetics of four fluorescent antagonists at human $\mathrm{A}_{3} \mathrm{AR}$. After $15 \mathrm{~min}$ pre-incubation with $0.5 \mu \mathrm{M}$ furimazine, Nluc$\mathrm{A}_{3}$ AR HEK293 cells were treated with the indicated concentrations of CA200645 (a), AV039 (b), XAC-S-ser-S-tyr-X-BYFL (c) or XAC-S-ser-

$S$-tyr-X-BY630 (d) and the NanoBRET signal was monitored at $37{ }^{\circ} \mathrm{C}$ every min for $60 \mathrm{~min}(\mathbf{a}-\mathbf{c})$ or $180 \mathrm{~min}(\mathbf{d})$. The data shown are mean \pm SEM and are representative examples from four $(\mathbf{a}, \mathbf{c})$ or five $(\mathbf{b}, \mathbf{d})$ independent experiments, each performed in triplicate

(min) obtained for the other three compounds. Additionally, it can be noted that the $\mathrm{pK}_{\mathrm{D}}$ values from saturation studies of $\mathrm{XAC}-S$-ser- $S$-tyr-X-BY630 and XAC- $S$-ser-S-tyr-X-BYFL are comparable to those obtained from the kinetic data, whereas for CA200645 and AV039, the saturation $\mathrm{pK}_{\mathrm{D}}$ values are significantly higher than the kinetic $\mathrm{pK}_{\mathrm{D}}$ (Table $1, p<0.05$, unpaired $t$ test).

\section{Radioligand binding characterisation of fluorescent probe}

To confirm the differences in the kinetics observed with AV039 and XAC- $S$-ser- $S$-tyr-X-BY630, radioligand equilibrium and kinetic binding assays in membranes from HEK293 cells stably expressing Nluc- $\mathrm{A}_{3} \mathrm{AR}$ were undertaken. Initially, the binding affinity and kinetic parameters of the radiolabelled $\mathrm{A}_{3} \mathrm{AR}$ antagonist $\left[{ }^{3} \mathrm{H}\right] \mathrm{PSB}-11$ at Nluc- $\mathrm{A}_{3} \mathrm{AR}$ were resolved from its association and dissociation curves at $10{ }^{\circ} \mathrm{C}$ (Fig. 4a, b; Table 2) and were similar to those obtained previously with the wild-type $\mathrm{A}_{3} \mathrm{AR}$ [30]. Next, the ability of XAC$S$-ser- $S$-tyr-X-BY630 and AV039 to compete at equilibrium with specific $\left[{ }^{3} \mathrm{H}\right] \mathrm{PSB}-11$ binding to the Nluc-A ${ }_{3}$ AR was examined (Fig. 4c) and the pKi for each of these compounds determined (Table 2). The affinities obtained in the radioligand binding assay for both fluorescent probes were lower than those obtained in the NanoBRET experiments

(Table 1), which may reflect differences in affinity values determined in whole cells compared to cell membranes, and also the impact of temperature $\left(10^{\circ} \mathrm{C}\right.$ versus $\left.37^{\circ} \mathrm{C}\right)$, as previously observed for the histamine $\mathrm{H}_{1}$ receptor [29].

The association and dissociation rates of XAC-S-ser-S-tyr$\mathrm{X}-\mathrm{BY} 630$ and AV039 were determined in kinetic association assays where the specific binding of $\left[{ }^{3} \mathrm{H}\right] \mathrm{PSB}-11$ in the presence and absence of a single concentration $\left(2 \times \mathrm{IC}_{50}\right)$ of the fluorescent ligand was monitored over time and the resulting data fitted to the model proposed by Motulsky and Mahan [27]. As expected from the kinetic behaviour observed in the NanoBRET assay, the association curve of $\left[{ }^{3} \mathrm{H}\right] \mathrm{PSB}-11$ obtained in the presence of AV039 quickly reached an equilibrium plateau (Fig. 4d) indicating that AV039 has a similar or faster kinetic profile compared to $\left[{ }^{3} \mathrm{H}\right] \mathrm{PSB}-11$. This was borne out in the kinetics parameters obtained from fitting the data to the Motulsky and Mahan model (Table 2). In comparison, $\mathrm{XAC}-S$-ser-S-tyr-X-BY630 induced an 'overshoot' in $\left[{ }^{3} \mathrm{H}\right] \mathrm{PSB}-11$ specific binding followed by a steady decrease (Fig. 4e) which is characteristic of long RT compounds. As such, both the association and dissociation rate constants of this fluorescent ligand are more than 10 times slower than those of $\mathrm{AV} 039$, whilst the $\mathrm{pK}_{\mathrm{D}}$ values are very similar. As a consequence, it was confirmed that XAC-S-ser- $S$-tyr-XBY630 had a long RT (over $7.5 \mathrm{~h}$ ) compared to AV039 and $\left[{ }^{3} \mathrm{H}\right] \mathrm{PSB}-11$. 
a

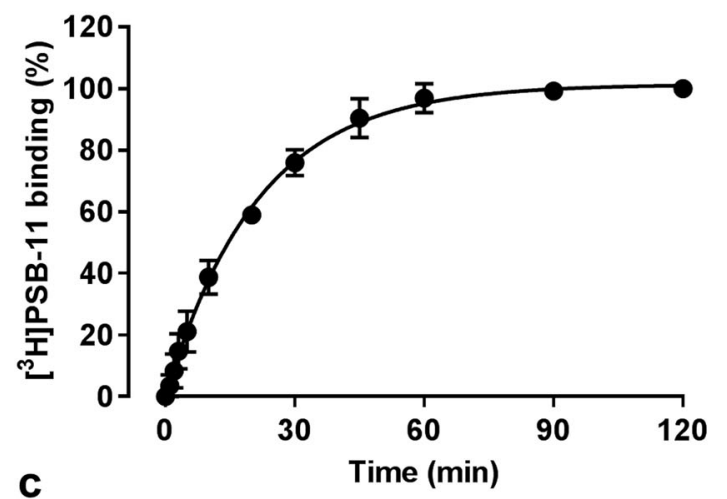

$c$

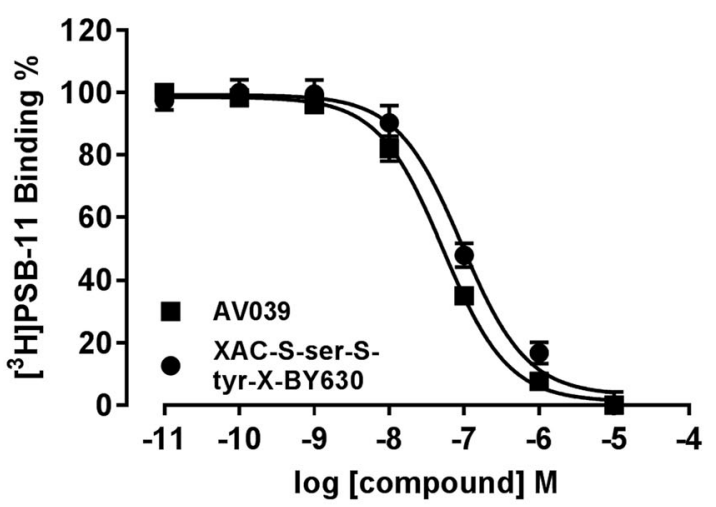

e

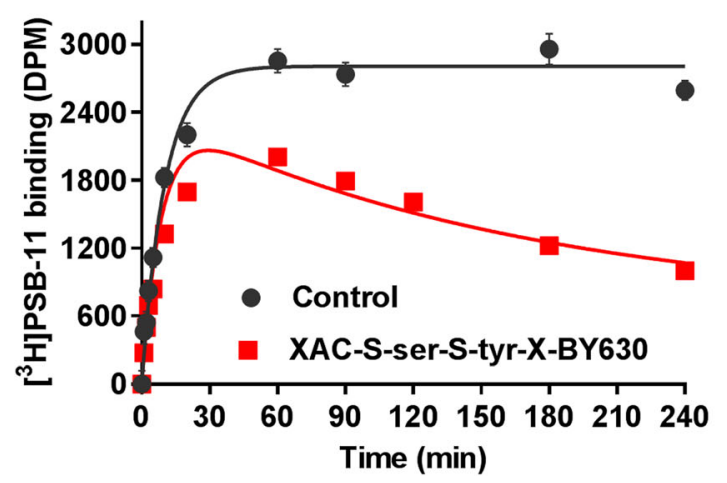

Fig. 4 Radioligand binding characterisation of fluorescent probes at human $\mathrm{A}_{3} \mathrm{AR}$. Association (a) and dissociation (b) curves of $10 \mathrm{nM}$ $\left[{ }^{3} \mathrm{H}\right]$ PSB-11 in Nluc-A $A_{3}$ AR HEK293 membranes performed at $10{ }^{\circ} \mathrm{C}$. Dissociation of the radioligand was initiated by addition of $10 \mu \mathrm{M}$ PSB-11 after equilibrium had been reached at $2 \mathrm{~h}$. Data were normalised to the maximal $\left.{ }^{3} \mathrm{H}\right] \mathrm{PSB}-11$ labelling in each experiment and shown as the mean and S.E.M. of five independent experiments performed in duplicate. c Nluc- $\mathrm{A}_{3} \mathrm{AR}$ membranes were treated with increasing concentrations of AV039 (squares) and XAC- $S$-ser- $S$-tyr-XBY630 (circles) and $10 \mathrm{nM}\left[{ }^{3} \mathrm{H}\right] \mathrm{PSB}-11$ in HEK293 Nluc- $\mathrm{A}_{3} \mathrm{AR}$

\section{Determination of the affinity and kinetic constants of unlabelled ligands}

To extend the use of the NanoBRET binding assay, it is necessary to use this setup to determine the kinetics of unlabelled ligands using the Motulsky and Mahan approach. To demonstrate its utility, it is important that the NanoBRET assay can b

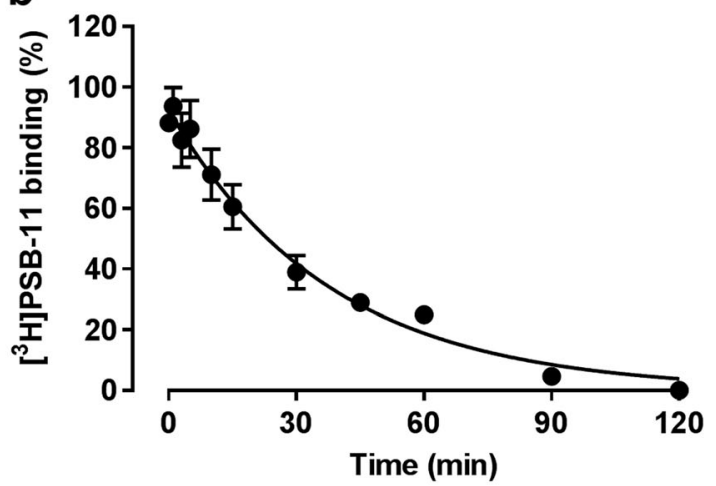

d

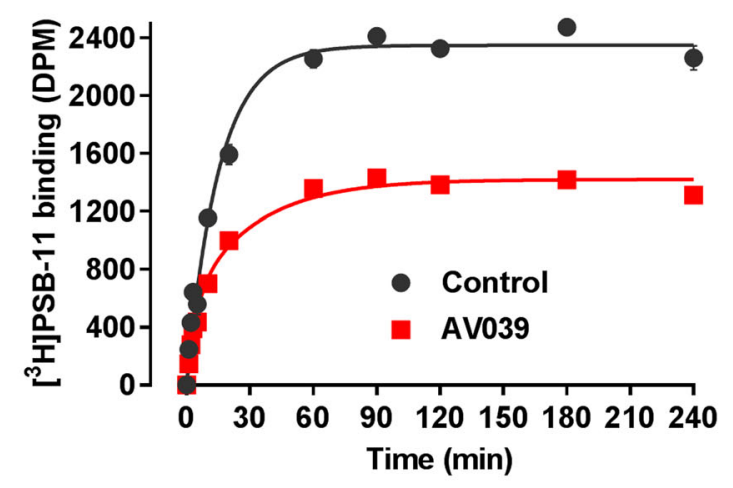

membranes at $10{ }^{\circ} \mathrm{C}$ to generate competition binding curves. Data were normalised to the maximal specific $\left[{ }^{3} \mathrm{H}\right] \mathrm{PSB}-11$ labelling in each experiment. Data points are combined mean \pm SEM from five separate experiments performed in duplicate. d, e Competition association time course of $\sim 10 \mathrm{nM}\left[{ }^{3} \mathrm{H}\right] \mathrm{PSB}-11$ on HEK293 Nluc-A 3 AR membranes at $10{ }^{\circ} \mathrm{C}$ in either absence (control, black circles) or presence of a single concentration $\left(2 \times K_{\mathrm{i}}\right.$ value) of AV039 (d, red squares) or XAC-S-ser- $S$ tyr-X-BY630 (e, red squares). The data shown are representative examples from four (d) and five (e) independent experiments performed in duplicate with each data point shown

distinguish between fast and slow unlabelled compounds. First, it was important to select unlabelled compounds with the desired kinetic profile. Using $\left[{ }^{3} \mathrm{H}\right] \mathrm{PSB}-11$ as the tracer, the kinetic parameters of two previously described high-affinity $\mathrm{A}_{3} \mathrm{AR}$ antagonists, compound 5 [36] (Fig. 1e) and LUF7565 [30] (Fig. 1f) were determined at Nluc- $\mathrm{A}_{3} \mathrm{AR}$. Competition binding experiments indicated compound 5 and LUF7565 
Table 2 Radioligand binding affinities and kinetic parameters of fluorescent probes and unlabelled ligands at the human $\mathrm{A}_{3} \mathrm{AR}$

\begin{tabular}{|c|c|c|c|c|c|c|c|}
\hline & \multicolumn{5}{|l|}{ Kinetics } & \multicolumn{2}{|c|}{ Equilibrium competition } \\
\hline & $\mathrm{pK}_{\mathrm{D}}$ & $k_{\mathrm{on}}\left(\times 10^{6} \mathrm{M}^{-1} \min ^{-1}\right)$ & $k_{\text {off }}\left(\min ^{-1}\right)$ & RT (min) & $n$ & $\mathrm{pK}_{\mathrm{i}}$ & $n$ \\
\hline$\left[{ }^{3} \mathrm{H}\right] \mathrm{PSB}-11$ & $8.04 \pm 0.08$ & $2.75 \pm 0.52$ & $0.023 \pm 0.002$ & $44.6 \pm 3.9$ & 5 & ND & ND \\
\hline AV039 & $7.63 \pm 0.08$ & $3.27 \pm 0.47$ & $0.076 \pm 0.009$ & $14.0 \pm 1.6$ & 5 & $7.65 \pm 0.02$ & 5 \\
\hline XAC-S-ser-S-tyr-X-BY630 & $7.74 \pm 0.08^{*}$ & $0.14 \pm 0.04$ & $0.0023 \pm 0.0002$ & $447 \pm 44$ & 4 & $7.21 \pm 0.06^{*}$ & 5 \\
\hline compound 5 & $7.53 \pm 0.13$ & $6.61 \pm 1.76$ & $0.198 \pm 0.045$ & $6.5 \pm 2.1$ & 4 & $7.35 \pm 0.02$ & 5 \\
\hline LUF7565 & $9.11 \pm 0.04^{*}$ & $8.17 \pm 0.95$ & $0.0065 \pm 0.0014$ & $168 \pm 25$ & 4 & $8.99 \pm 0.02 *$ & 5 \\
\hline
\end{tabular}

$\mathrm{pK}_{\mathrm{i}}$ values were calculated from inhibition of equilibrium $\left[{ }^{3} \mathrm{H}\right] \mathrm{PSB}-11$ binding to Nluc- $\mathrm{A}_{3} \mathrm{AR}$ HEK 293 membranes at $10{ }^{\circ} \mathrm{C}$. The kinetic parameters, $k_{\mathrm{on}}, k_{\mathrm{off}}$ and $\mathrm{pK}_{\mathrm{D}}$ values of PSB-11 were obtained from association and dissociation curves of $\left.10 \mathrm{nM} \mathrm{[}{ }^{3} \mathrm{H}\right] \mathrm{PSB}-11$ in Nluc-A $\mathrm{A}_{3}$ AR HEK293 membranes at $10{ }^{\circ} \mathrm{C}$. Radioligand dissociation was initiated by the addition of $10 \mu \mathrm{M}$ unlabeled PSB-11. The kinetic parameters, $k_{\mathrm{on}}, k_{\mathrm{off}}$ and pK $\mathrm{D}_{\mathrm{D}}$ values of AV039, XAC-S-ser-S-tyr-X-BY630, compound 5 and LUF7565 were obtained by competition association with $\sim 10 \mathrm{nM}\left[{ }^{3} \mathrm{H}\right] \mathrm{PSB}-11$ at $10{ }^{\circ} \mathrm{C}$. The RT was calculated as the reciprocal of the $k_{\text {off }}$ values from each individual experiment. All values represent mean $\pm \operatorname{SEM}$ from $n$ separate experiments performed in duplicate

$N D$ not determined

$* p<0.05$, kinetic $\mathrm{pK}_{\mathrm{D}}$ versus equilibrium competition $\mathrm{pK}_{\mathrm{i}}$ values according to unpaired Student's $t$ test

gave a concentration-dependent inhibition of the specific binding of $\left[{ }^{3} \mathrm{H}\right] \mathrm{PSB}-11$ with LUF7565 displaying higher
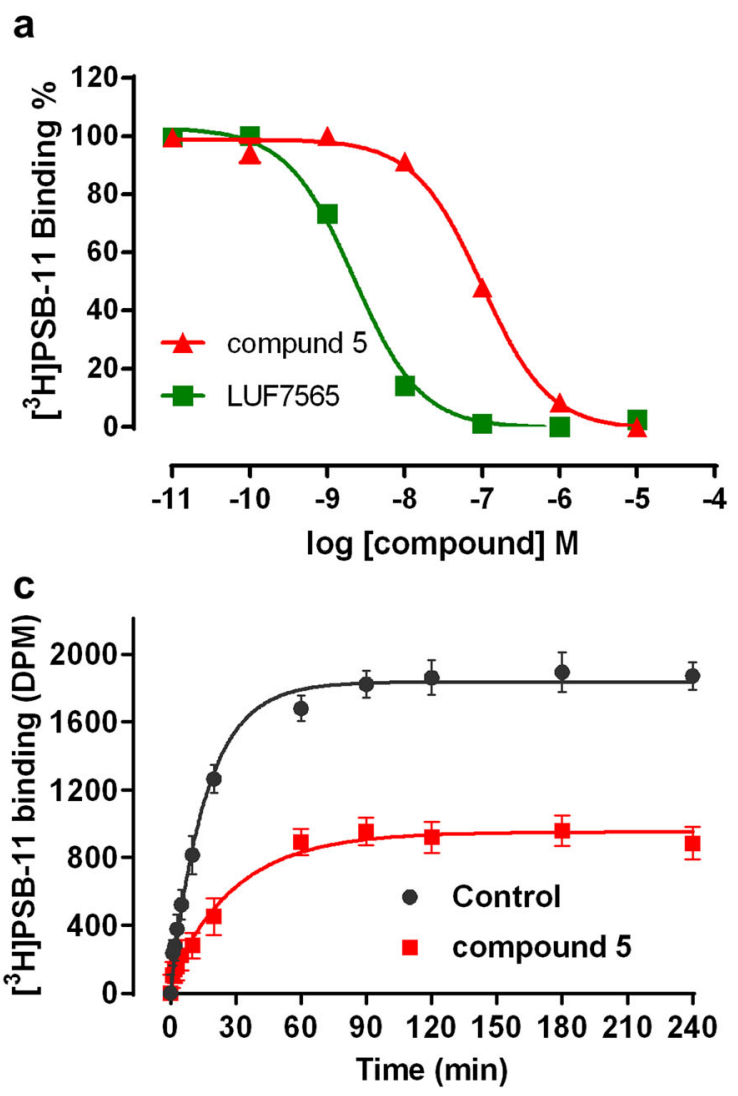

Fig. 5 Radioligand binding characterisation of unlabelled ligands at human $\mathrm{A}_{3} \mathrm{AR}$. a HEK293 membranes expressing human Nluc- $\mathrm{A}_{3} \mathrm{AR}$ were treated with increasing concentrations of compound 5 (red triangles) and LUF7565 (green squares), and $10 \mathrm{nM}\left[{ }^{3} \mathrm{H}\right] \mathrm{PSB}-11$ at $10{ }^{\circ} \mathrm{C}$ for $2 \mathrm{~h}$ and levels of $\left[{ }^{3} \mathrm{H}\right] \mathrm{PSB}-11$ binding monitored by scintillation counting. Data were normalised to the maximal specific $\left[{ }^{3} \mathrm{H}\right]$ PSB-11 labelling in each experiment. Data points are combined affinity for Nluc-A $\mathrm{A}_{3} \mathrm{AR}$ than compound 5 (Fig. 5a; Table 2). The association and dissociation rate constants of compound 5

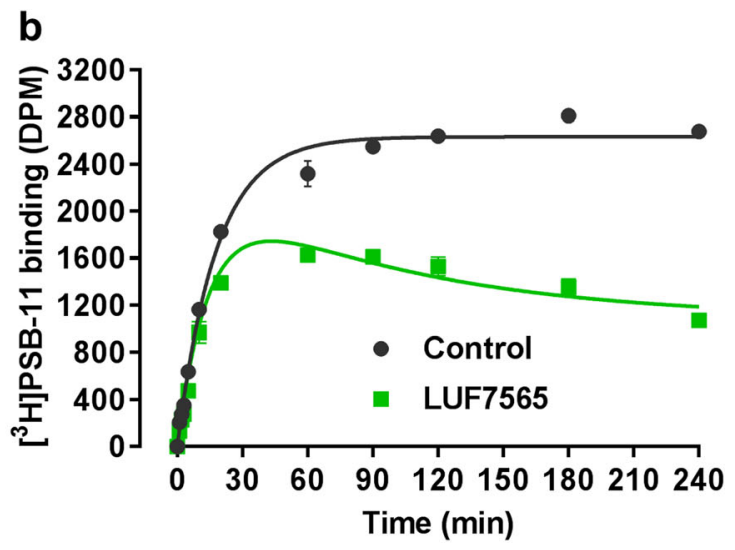

mean \pm SEM from five separate experiments performed in duplicate. $\mathbf{b}$, c Association of $\left[{ }^{3} \mathrm{H}\right] \mathrm{PSB}-11$ on Nluc- $\mathrm{A}_{3}$ AR HEK293 membranes at $10{ }^{\circ} \mathrm{C}$ in the absence (control, black circles) or presence of a single concentration $\left(2 \times K_{\mathrm{i}}\right.$ value) of and LUF7565 (b) or compound 5 (c). The data shown are representative examples from four independent experiments performed in duplicate with each data point shown 
and LUF7565 were then determined from the decrease in the specific binding of $\left[{ }^{3} \mathrm{H}\right] \mathrm{PSB}-11$ in the presence of a single concentration $\left(2 \times \mathrm{IC}_{50}\right)$ of the unlabelled ligands. The competition association curve of compound 5 (Fig. 5c) exhibited the kinetic profile of a short RT ligand, while LUF7565 induced an 'overshoot' in the [ $\left.{ }^{3} \mathrm{H}\right] \mathrm{PSB}-11$-specific binding (Fig. $5 b)$ which is the characteristic profile of a long RT compound, and this was confirmed from the calculated kinetic parameters (Table 2). Radioligand kinetic affinity was comparable to that obtained by radioligand displacement for both the unlabelled ligands.

The selective $\mathrm{A}_{3} \mathrm{AR}$ fluorescent antagonist AV039 was chosen as a short RT probe to evaluate the affinity and kinetic parameters of compound 5, LUF7565 alongside those of PSB11. Initially, the affinity of these three antagonists was determined in an equilibrium competition assay using $20 \mathrm{nM}$ AV039 in HEK 293 cells stably expressing the Nluc-A $A_{3}$ AR (Fig. 6a; Table 3). As expected, all three ligands exhibited high affinity for the $\mathrm{A}_{3} \mathrm{AR}$, confirming the data obtained using $\left[{ }^{3} \mathrm{H}\right] \mathrm{PSB}-11$. To further investigate the properties of these compounds, their binding kinetic parameters were determined using AV039 as the probe. The time-dependent decrease in the association binding of AV039 induced by the addition of different concentrations of PSB-11, compound 5 and LUF7565 was monitored at $37^{\circ} \mathrm{C}$ (Fig. $6 \mathrm{~b}-\mathrm{d}$ ) to determine the kinetic parameters of these unlabelled compounds. The competition association curves of PSB-11 (Fig. 6b) and compound 5 (Fig. $6 c)$ exhibited the typical kinetic profile of a short RT ligand, while LUF7565 (Fig. 6d) induced a very pronounced initial overshoot in binding of AV039 followed by a decrease which is characteristic of a long RT compound. As expected from the shape of the competition association curves, LUF7565 was found to have the slowest dissociation rate and subsequently the longest RT (Table 3). The kinetic $\mathrm{pK}_{\mathrm{D}}$ of the short RT compounds PSB-11 and compound 5 was similar to the equilibrium $\mathrm{pK}_{\mathrm{i}}$, while for the slow dissociation compound LUF7565, the kinetic $\mathrm{pK}_{\mathrm{D}}$ was significantly higher than $\mathrm{pK}_{\mathrm{i}}$ $(p<0.05$, unpaired $t$ test).

As XAC-S-ser-S-tyr-X-BY630 was found to have a considerably longer RT than AV039 and $\left[{ }^{3} \mathrm{H}\right] \mathrm{PSB}-11$, it was used to investigate the effect of the RT and binding kinetic parameters of the labelled probe on the measured kinetic parameters of unlabelled ligands. Firstly, it was confirmed that PSB-11, compound 5 and LUF7565 inhibited the specific XAC-S-ser$S$-tyr-X-BY630 binding in a concentration-dependent manner in Nluc-A 3 AR HEK 293 cells (Fig. 7a; Table 3). It was noted that the affinity obtained for all the compounds was around half a log unit lower than the $\mathrm{pK}_{\mathrm{i}}$ value obtained with AV039,
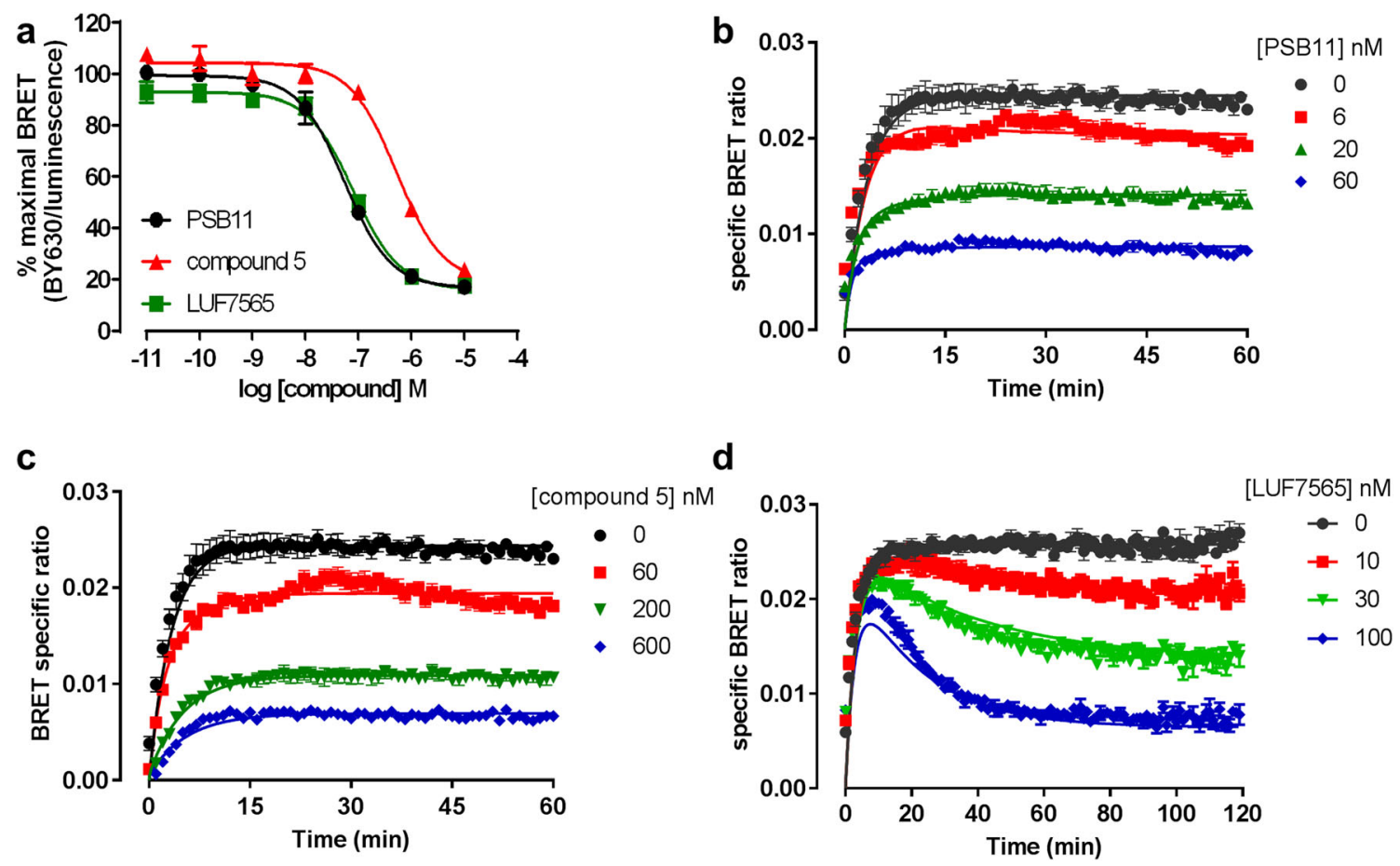

Fig. 6 Characterisation of the effect of unlabelled ligands on the binding of AV039 to Nluc- $\mathrm{A}_{3}$ AR using NanoBRET (a). Nluc-A $A_{3}$ AR cells were treated with $50 \mathrm{nM} \mathrm{AV039}$ and increasing concentrations of PSB-11 (black circles), compound 5 (red triangles) and LUF7565 (green squares) for $1 \mathrm{~h}$ at $37{ }^{\circ} \mathrm{C}$ and competition binding curves generated. Data were normalised to the maximal BRET signal in each experiment. Data points are combined mean \pm SEM from five separate experiments performed in triplicate. b-d After 15 min pre-incubation with $0.5 \mu \mathrm{M}$

furimazine, the association rate of $40 \mathrm{nM}$ AV039 was monitored, via NanoBRET, at $37^{\circ} \mathrm{C}$ in HEK293 cells expressing human Nluc-A $A_{3} \mathrm{AR}$ in the absence (control, black circles) or presence of the indicated concentrations of PSB-11 (b), compound 5 (c) and LUF7565 (d). The data shown are representative examples from five $(\mathbf{b}, \mathbf{c})$ or six $(\mathbf{d})$ independent experiments performed in triplicate, and the depicted data points represent the mean \pm SEM of the triplicates 
but exhibited the same trend, with PSB-11 displaying the highest affinity at $\mathrm{A}_{3} \mathrm{AR}$ and compound 5 the least potent.

The concentration-dependent decrease in the association binding of XAC-S-ser-S-tyr-X-BY630 induced by the addition of different concentrations of PSB-11, compound 5 and LUF7565 allowed us to determine the association and dissociation rates of these unlabelled compounds when using a long RT compound as the probe. The competition association curves obtained in the presence of all three unlabelled ligands showed a continuous increase in XAC-S-ser-S-tyr-X-BY630 signal parallel to that observed with the fluorescent ligand only (Fig. 7b-d). Only a small initial overshoot in binding was observed in the presence of 100 and $300 \mathrm{nM}$ of LUF7565. The kinetic parameters obtained for all ligands are presented in Table 3 . The kinetic $\mathrm{pK}_{\mathrm{D}}$ for compound 5 and PSB-11 was similar to that obtained at equilibrium, while LUF7565's kinetic $\mathrm{pK}_{\mathrm{D}}$ was slightly higher than the equilibrium $\mathrm{pK}_{\mathrm{i}}$. In comparison to the kinetic parameters obtained with AV039, the $k_{\text {on }}$ values were lower when using XAC-Sser-S-tyr-X-BY630 as the probe for all three unlabelled compounds. For PSB-11 and compound 5, an increase in RT was observed with XAC-S-ser- $S$-tyr-X-BY630 in comparison to that with AV039, whereas a decrease in the RT of LUF7565 was seen.

\section{Discussion}

It is becoming increasingly clear that a ligand's binding kinetics are a crucial part of its pharmacology which can play a role in its success in the clinic $[16,18,20]$. In this study, we set out to develop an assay to determine the kinetic parameters of molecules binding to the $\mathrm{A}_{3} \mathrm{AR}$ using NanoBRET in living cells and at physiological temperatures. We also compared the values obtained to those obtained in a more classical radioligand binding assay that used cell membrane preparations and was performed at much lower temperatures $\left(10^{\circ} \mathrm{C}\right)$. We found that kinetic parameters of unlabelled ligands obtained in both assays were comparable when using a labelled probe with similar kinetics (AV039 versus $\left[{ }^{3} \mathrm{H}\right] \mathrm{PSB}-11$ ). Moreover, when a long RT probe (XAC-S-ser- $S$-tyr-XBY630) was used, it was difficult to resolve the differences in kinetic parameters of a fast and slow unlabelled compound. This indicates that the kinetic profile of the labelled probe can influence the range of $k_{\text {on }}$ and $k_{\text {off }}$ values that can be accurately determined.

For many years, the toolbox available for studying binding kinetics at GPCRs was limited to the use of radioligand binding assays [14]. With the increasing range of fluorescent ligands available for the study of GPCRs alongside more suitable proteins for use in energy transfer techniques (such as NanoLuc and SNAP), there has been increased interest in adapting these techniques to measure ligand-binding kinetics 


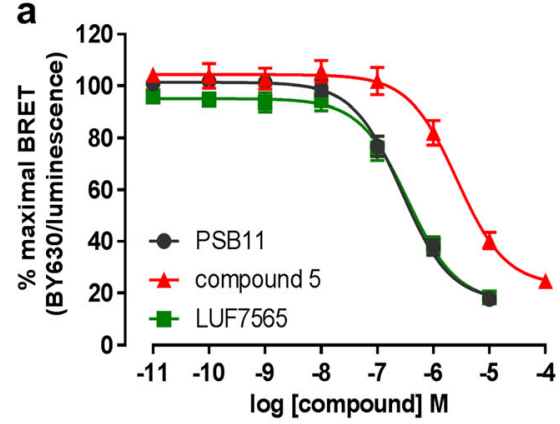

C

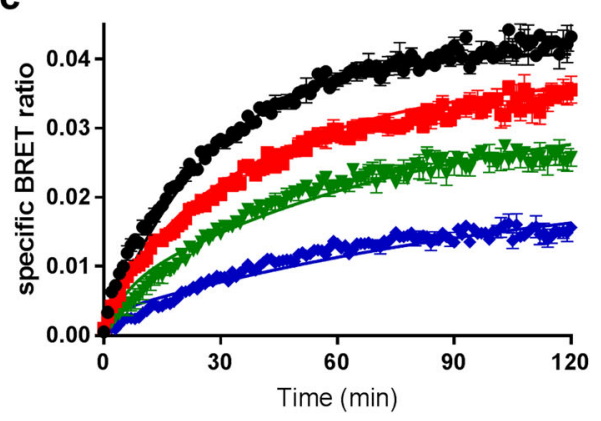

Fig. 7 Characterisation of the effect of unlabelled ligands on the binding of XAC-S-ser-S-tyr-X-BY630 to Nluc- $\mathrm{A}_{3}$ AR using NanoBRET. a Nluc$\mathrm{A}_{3} \mathrm{AR}$ cells were treated with $40 \mathrm{nM}$ XAC-S-ser-S-tyr-X-BY630 and increasing concentrations of PSB-11 (black circles), compound 5 (red triangles) and LUF7565 (green squares) for $3 \mathrm{~h}$ at $37^{\circ} \mathrm{C}$ and competition binding curves generated. Data were normalised to the maximal BRET signal in each experiment. Data points are combined mean \pm SEM from five (PSB-11) or six (compound 5 and LUF7565) separate experiments

[26]. Here, we have developed a BRET-based kinetic assay for the $A_{3} A R$. This is particularly important for the $A_{3} A R$, as historically there has only been a radiolabelled agonist commercially available, and radiolabelled antagonists, such as the one used in this study, have to be custom synthesised [35]. The $\mathrm{A}_{3} \mathrm{AR}$ offered a unique opportunity for this since multiple fluorescent ligands based on different parent molecules have been described in the literature and one of these ligands is commercially available [32-34]. Three of these fluorescent ligands measured in this study were based on the nonselective adenosine receptor antagonist XAC. Two of these ligands, CA200645 and XAC-S-ser-S-tyr-X-BYFL, were found to have similar $k_{\text {on }}$ and $k_{\text {off }}$ rate constants, whereas XAC- $S$-ser- $S$-tyr-X-BY630 had a similar value for $k_{\text {on }}$ but a much slower $k_{\text {off }}$ rate constant. In the development of fluorescent ligands with improved imaging properties, incorporation of a peptide linker between the pharmacophore and fluorophore was found to prevent the ligand from crossing the cell membrane in a non-specific manner [29, 33]. Molecular modelling has suggested that this linker region makes additional contacts at the top of the transmembrane domains of the receptor and that the fluorophore is buried within the lipid environment of the plasma membrane [33]. This has also been observed in molecular modelling of fluorescent ligands binding to the histamine $H_{1}$ receptor [29].
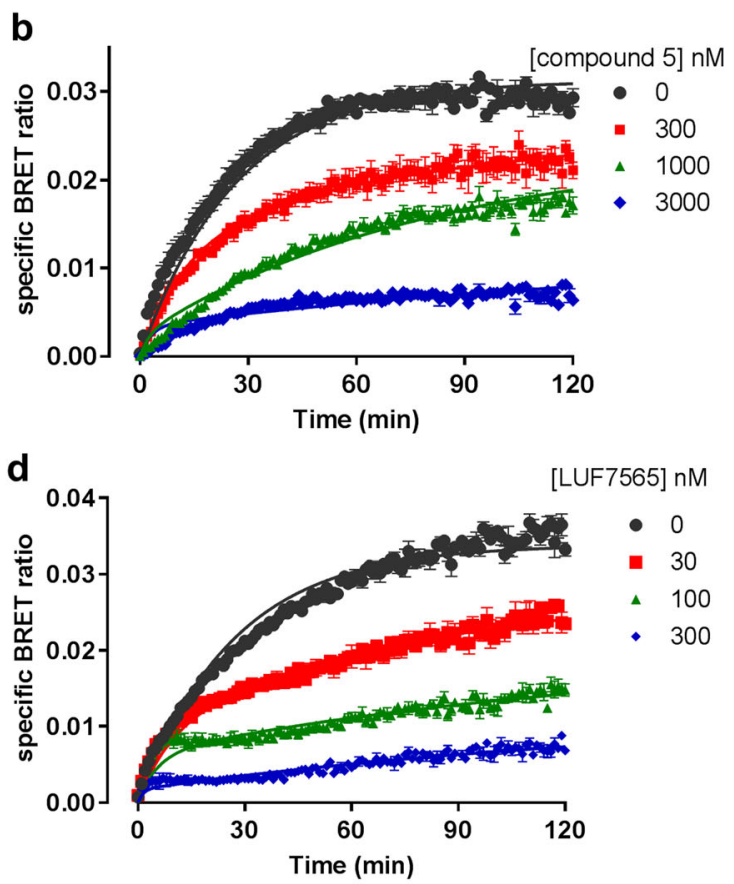

performed in triplicate. b-d The association of $20 \mathrm{nM} X \mathrm{XAC}-S$-ser- $S$-tyrX-BY630 on HEK293 cells expressing human Nluc- $\mathrm{A}_{3}$ AR at $37{ }^{\circ} \mathrm{C}$ was monitored at the indicated times by NanoBRET in either absence (control, black circles) or presence of various concentrations of compound 5 (b), PSB 11 (c) and LUF7565 (d). The data shown are representative examples from four $(\mathbf{b}, \mathbf{c})$ or five (d) independent experiments performed in triplicate, and the depicted data points represent the mean \pm SEM of the triplicates

Other studies that have developed fluorescent ligands have also found that the fluorophore can influence the affinity of the resulting molecule $[39,40]$. It is therefore clear that the fluorophore portion of fluorescent ligand is not a passive part of the molecule but can influence both the affinity and binding kinetics. The chemical structures of XAC-S-ser- $S$-tyr-XBY630 and XAC-S-ser-S-tyr-X-BYFL are very similar and only differ in the structure of the fluorophore. It has previously been shown with the $\beta_{2}$-adrenoceptor that the interaction of ligands with the membrane influences the observed association rates [41]. The interaction of a ligand with a membrane can create a micro-environment which can alter the observed kinetic profiles [42]. It is possible that the BODIPY fluorophores interact differently with the cell membrane to increase the RT of XAC-S-ser-S-tyr-X-BY630 compared to $\mathrm{XAC}-S$-ser-S-tyr-X-BYFL. It is worth noting, however, that the mere presence of a BY630 fluorophore is not a determinant for a longer RT compound since both CA200645 and AV039 contain the same fluorophore.

The availability of a radiolabelled antagonist, $\left[{ }^{3} \mathrm{H}\right] \mathrm{PSB}-11$, allowed us to compare the kinetic parameters of unlabelled ligands, measured using either long or short RT fluorescent ligand in the NanoBRET assay, with those obtained in a more traditional radioligand binding assay. We found that the $k_{\text {on }}$ rate constants measured with all three unlabelled ligands were 
all within a similar range (Table 2) although the rank order within data sets was not the same. For example, LUF7565 was found to have the fastest association rate when either $\left[{ }^{3} \mathrm{H}\right] \mathrm{PSB}-11$ or XAC-S-ser- $S$-tyr-X-BY630 were used as the probe, whereas LUF7565 had the slowest association rate when measured against AV039. Although here we have only compared the kinetic parameters of three compounds, this is similar to previous studies comparing the kinetic parameters of GnRH ligands determined using radioligand binding and time-resolved FRET (TR-FRET) where no correlation between association rates was found in the two assay setups [43].

In comparison to the tight range of $k_{\mathrm{on}}$ values, there was a wider range of measured $k_{\mathrm{off}}$ values. For both $\left[{ }^{3} \mathrm{H}\right] \mathrm{PSB}-11$ and AV039, there was between a 30- and 94-fold difference, respectively, in the $k_{\text {off }}$ values measured for compound 5 and LUF7565, with LUF7565 displaying the slowest $k_{\text {off }}$ of the measured unlabelled compounds using both probes. This indicates that for both these probes, a wide range of kinetic parameters can be measured. As seen in Fig. 7, the profile of the competition association curves with each of the three unlabelled compounds was comparable, and this is reflected in the similarities in the kinetic parameters obtained. To date, LUF7565 is one of the longest residence time unlabelled ligands reported at $\mathrm{A}_{3} \mathrm{AR}$, and it may be that XAC-S-ser-S-tyrX-BY630 will be a useful tool to find even longer RT compounds at this receptor.

Although a similar trend was seen for the $k_{\text {off }}$ values determined using $\left[{ }^{3} \mathrm{H}\right] \mathrm{PSB}-11$ and AV039, 10-fold higher $k_{\text {off }}$ values were determined for PSB-11 and compound 5 when using AV039, leading to compounds with apparently shorter RT. There are many differences in setup of the two assays which could lead to these differences and need to be kept in mind when comparing the data sets. One of the main differences is that the radioligand binding assay uses membrane preparations, whereas the BRET assays are performed on intact cells. The intact cell environment preserves all of the intracellular proteins that a GPCR can interact with, and these are known to be able to stabilise different conformations of the receptor which in turn may affect the binding kinetics of the ligands [44, 45]. As these interacting proteins include $G$ proteins and arrestins, preservation of the intact cellular environment allows downstream signalling and internalisation to still occur. It is unlikely that internalisation plays a role in this study since XAC$S$-ser-S-tyr-X-BY630 and AV039 have previously been shown to be competitive antagonists, and in confocal imaging studies, there was no indication that these ligands caused internalisation of the $\mathrm{A}_{3} \mathrm{AR}$ [33, 34]. Although it appears that these fluorescent ligands do not cause internalisation of the receptor, it is possible that the antagonist bound form of the receptor may interact with different adaptor proteins and this may underpin some of the differences observed. Differences in binding kinetics have also been observed previously when comparing measurements from membrane preparations and whole cells at other GPCRs including the dopamine $D_{2 L}$ receptor [46] and histamine $H_{1}$ receptor [29]. For the $D_{2 L}$ receptor, it was suggested that differences in dissociation rates are a reflection of how the ligand interacts with the cell membrane [46]. Apart from receptor environment, the two assay setups were performed at different temperatures - radioligand binding at $10{ }^{\circ} \mathrm{C}$ and BRET at $37{ }^{\circ} \mathrm{C}$ - and it can be assumed from basic thermodynamic principles that both association and dissociation rates will increase with temperature. Due to the rapid kinetics of $\left[{ }^{3} \mathrm{H}\right] \mathrm{PSB}-11$, the competition association assay is challenging to perform at higher temperature [30], and since the plate reader used for the live cell assay lacks the capacity to be actively cooled, we are unable at the present time to directly test this. An increase in association and dissociation rate with temperature has been observed for the histamine $\mathrm{H}_{1}$ receptor [47] and the prolactin receptor [48].

In summary, this study has demonstrated that a NanoBRET-based assay can be applied to measure ligandbinding kinetics at the $\mathrm{A}_{3} \mathrm{AR}$ in intact living cells at physiological temperatures. The data shown here do, however, indicate that care needs to be taken when selecting a probe with the appropriate kinetics for the study of unlabelled ligands with different kinetic profiles. Thus, probes with very slow kinetics may be problematic for the determination of the kinetic parameters of unlabelled ligands with rapid kinetic properties. As the range of fluorescent ligands for GPCRs continues to expand [49], their use in NanoBRET-based assays should provide the required diversity of kinetic properties to evaluate the kinetic profiles of the broadest range of unlabelled ligands in a physiologically relevant setting.

Acknowledgments This work was supported by the Medical Research Council (grant number MR/N020081/1) and the Innovative Medicines Initiative Joint Undertaking K4DD under grant agreement 115366, resources of which are composed of financial contribution from the European Union's Seventh Framework Programme (FP7/2007-2013) and European Federation of Pharmaceutical Industries and Associations (EFPIA) companies' in-kind contribution.

\section{Compliance with ethical standards}

Conflicts of interest Monica Bouzo-Lorenzo declares that she has no conflict of interest. Leigh A. Stoddart declares that she has no conflict of interest. Lizi Xia declares that he has no conflict of interest. Adriaan P. IJzerman declares that he has no conflict of interest. Laura H. Heitman declares that she has no conflict of interest. Stephen J Briddon declares that he has no conflict of interest. Stephen J Hill declares that he has no conflict of interest.

Ethical approval This article does not contain any studies with human participants or animals performed by any of the authors. 
Open Access This article is distributed under the terms of the Creative Commons Attribution 4.0 International License (http:// creativecommons.org/licenses/by/4.0/), which permits unrestricted use, distribution, and reproduction in any medium, provided you give appropriate credit to the original author(s) and the source, provide a link to the Creative Commons license, and indicate if changes were made.

\section{References}

1. Elliott MR, Chekeni FB, Trampont PC, Lazarowski ER, Kadl A, Walk SF, Park D, Woodson RI, Ostankovich M, Sharma P, Lysiak JJ, Harden TK, Leitinger N, Ravichandran KS (2009) Nucleotides released by apoptotic cells act as a find-me signal to promote phagocytic clearance. Nature 461(7261):282-286. https://doi.org/ 10.1038/nature08296

2. Okada SF, Nicholas RA, Kreda SM, Lazarowski ER, Boucher RC (2006) Physiological regulation of ATP release at the apical surface of human airway epithelia. J Biol Chem 281(32):22992-23002. https://doi.org/10.1074/jbc.M603019200

3. Picher M, Burch LH, Hirsh AJ, Spychala J, Boucher RC (2003) Ecto 5'-nucleotidase and nonspecific alkaline phosphatase. Two AMP-hydrolyzing ectoenzymes with distinct roles in human airways. J Biol Chem 278(15):13468-13479. https://doi.org/10. 1074/jbc.M300569200

4. Fredholm BB, IJzerman AP, Jacobson KA, Linden J, Müller CE (2011) International Union of Basic and Clinical Pharmacology. LXXXI. Nomenclature and classification of adenosine receptors: an update. Pharmacol Rev 63(1):1-34. https://doi.org/10.1124/pr. 110.003285

5. Jacobson KA, Merighi S, Varani K, Borea PA, Baraldi S, Aghazadeh Tabrizi M, Romagnoli R, Baraldi PG, Ciancetta A, Tosh DK, Gao ZG, Gessi S (2017) A3 adenosine receptors as modulators of inflammation: from medicinal chemistry to therapy. Med Res Rev 38(4):1031-1072. https://doi.org/10.1002/med. 21456

6. Germack R, Dickenson JM (2004) Characterization of ERK1/2 signalling pathways induced by adenosine receptor subtypes in newborn rat cardiomyocytes. Br J Pharmacol 141(2):329-339. https://doi.org/10.1038/sj.bjp.0705614

7. McIntosh VJ, Lasley RD (2012) Adenosine receptor-mediated cardioprotection: are all 4 subtypes required or redundant? J Cardiovasc Pharmacol Ther 17(1):21-33. https://doi.org/10.1177/ 1074248410396877

8. Pugliese AM, Coppi E, Volpini R, Cristalli G, Corradetti R, Jeong LS, Jacobson KA, Pedata F (2007) Role of adenosine A3 receptors on CA1 hippocampal neurotransmission during oxygen-glucose deprivation episodes of different duration. Biochem Pharmacol 74(5):768-779. https://doi.org/10.1016/j.bcp.2007.06.003

9. Rivera-Oliver M, Diaz-Rios M (2014) Using caffeine and other adenosine receptor antagonists and agonists as therapeutic tools against neurodegenerative diseases: a review. Life Sci 101(1-2): 1-9. https://doi.org/10.1016/j.lfs.2014.01.083

10. Fishman P, Bar-Yehuda S, Barer F, Madi L, Multani AS, Pathak S (2001) The A3 adenosine receptor as a new target for cancer therapy and chemoprotection. Exp Cell Res 269(2):230-236. https:// doi.org/10.1006/excr.2001.5327

11. Fishman P, Bar-Yehuda S, Liang BT, Jacobson KA (2012) Pharmacological and therapeutic effects of A3 adenosine receptor agonists. Drug Discov Today 17(7-8):359-366. https://doi.org/10. 1016/j.drudis.2011.10.007

12. Hauser RA, Stocchi F, Rascol O, Huyck SB, Capece R, Ho TW, Sklar P, Lines C, Michelson D, Hewitt D (2015) Preladenant as an adjunctive therapy with levodopa in Parkinson disease: two randomized clinical trials and lessons learned. JAMA Neurol 72(12): 1491-1500. https://doi.org/10.1001/jamaneurol.2015.2268

13. Waring MJ, Arrowsmith J, Leach AR, Leeson PD, Mandrell S, Owen RM, Pairaudeau G, Pennie WD, Pickett SD, Wang J, Wallace O, Weir A (2015) An analysis of the attrition of drug candidates from four major pharmaceutical companies. Nat Rev Drug Discov 14(7):475-486. https://doi.org/10.1038/nrd4609

14. Guo D, Hillger JM, AP IJ, Heitman LH (2014) Drug-target residence time - a case for G protein-coupled receptors. Med Res Rev 34(4):856-892. https://doi.org/10.1002/med.21307

15. Vauquelin G (2016) Effects of target binding kinetics on in vivo drug efficacy: koff, kon and rebinding. Br J Pharmacol 173(15): 2319-2334. https://doi.org/10.1111/bph.13504

16. Schuetz DA, de Witte WEA, Wong YC, Knasmueller B, Richter L, Kokh DB, Sadiq SK, Bosma R, Nederpelt I, Heitman LH, Segala E, Amaral M, Guo D, Andres D, Georgi V, Stoddart LA, Hill S, Cooke RM, De Graaf C, Leurs R, Frech M, Wade RC, de Lange ECM, AP IJ, Muller-Fahrnow A, Ecker GF (2017) Kinetics for drug discovery: an industry-driven effort to target drug residence time. Drug Discov Today 22(6):896-911. https://doi.org/10.1016/j.drudis. 2017.02.002

17. Swinney DC, Haubrich BA, Van Liefde I, Vauquelin G (2015) The role of binding kinetics in GPCR drug discovery. Curr Top Med Chem 15(24):2504-2522. https://doi.org/10.2174/ 1568026615666150701113054

18. Copeland RA, Pompliano DL, Meek TD (2006) Drug-target residence time and its implications for lead optimization. Nat Rev Drug Discov 5(9):730-739. https://doi.org/10.1038/nrd2082

19. Beeh KM, Westerman J, Kirsten AM, Hebert J, Gronke L, Hamilton A, Tetzlaff K, Derom E (2015) The 24-h lung-function profile of once-daily tiotropium and olodaterol fixed-dose combination in chronic obstructive pulmonary disease. Pulm Pharmacol Ther 32:53-59. https://doi.org/10.1016/j.pupt.2015.04.002

20. Tautermann CS (2016) Impact, determination and prediction of drug-receptor residence times for GPCRs. Curr Opin Pharmacol 30:22-26. https://doi.org/10.1016/j.coph.2016.07.004

21. Vauquelin G (2016) Cell membranes... and how long drugs may exert beneficial pharmacological activity in vivo. Br J Clin Pharmacol 82(3):673-682. https://doi.org/10.1111/bcp.12996

22. Kapur S, Seeman P (2001) Does fast dissociation from the dopamine d(2) receptor explain the action of atypical antipsychotics?: a new hypothesis. Am J Psychiatry 158(3):360-369. https://doi.org/ 10.1176/appi.ajp.158.3.360

23. Segala E, Errey JC, Fiez-Vandal C, Zhukov A, Cooke RM (2015) Biosensor-based affinities and binding kinetics of small molecule antagonists to the adenosine $\mathrm{A}(2 \mathrm{~A})$ receptor reconstituted in HDL like particles. FEBS Lett 589(13):1399-1405. https://doi.org/10. 1016/j.febslet.2015.04.030

24. Aristotelous T, Ahn S, Shukla AK, Gawron S, Sassano MF, Kahsai AW, Wingler LM, Zhu X, Tripathi-Shukla P, Huang XP, Riley J, Besnard J, Read KD, Roth BL, Gilbert IH, Hopkins AL, Lefkowitz RJ, Navratilova I (2013) Discovery of beta2 adrenergic receptor ligands using biosensor fragment screening of tagged wild-type receptor. ACS Med Chem Lett 4(10):1005-1010. https://doi.org/ $10.1021 / \mathrm{ml} 400312 \mathrm{j}$

25. Hoffmann C, Castro M, Rinken A, Leurs R, Hill SJ, Vischer HF (2015) Ligand residence time at G-protein-coupled receptors-why we should take our time to study it. Mol Pharmacol 88(3):552-560. https://doi.org/10.1124/mol.115.099671

26. Stoddart LA, White CW, Nguyen K, Hill SJ, Pfleger KD (2016) Fluorescence- and bioluminescence-based approaches to study GPCR ligand binding. Br J Pharmacol 173(20):3028-3037. https://doi.org/10.1111/bph.13316 
27. Motulsky HJ, Mahan LC (1984) The kinetics of competitive radioligand binding predicted by the law of mass action. Mol Pharmacol 25(1):1-9

28. Schiele F, Ayaz P, Fernandez-Montalvan A (2014) A universal homogeneous assay for high-throughput determination of binding kinetics. Anal Biochem 468C:42-49. https://doi.org/10.1016/j.ab. 2014.09.007

29. Stoddart LA, Vernall AJ, Bouzo-Lorenzo M, Bosma R, Kooistra AJ, de Graaf C, Vischer HF, Leurs R, Briddon SJ, Kellam B, Hill SJ (2018) Development of novel fluorescent histamine H1-receptor antagonists to study ligand-binding kinetics in living cells. Sci Rep 8(1):1572. https://doi.org/10.1038/s41598-018-19714-2

30. Xia L, Burger WAC, van Veldhoven JPD, Kuiper BJ, van Duijl TT, Lenselink EB, Paasman E, Heitman LH, AP IJ (2017) Structureaffinity relationships and structure-kinetics relationships of pyrido[2,1-f]purine-2,4-dione derivatives as human adenosine A3 receptor antagonists. J Med Chem 60(17):7555-7568. https://doi. org/10.1021/acs.jmedchem.7b00950

31. Zeilinger M, Pichler F, Nics L, Wadsak W, Spreitzer H, Hacker M, Mitterhauser M (2017) New approaches for the reliable in vitro assessment of binding affinity based on high-resolution real-time data acquisition of radioligand-receptor binding kinetics. EJNMMI Res 7(1):22. https://doi.org/10.1186/s13550-016-0249-9

32. Stoddart LA, Vernall AJ, Denman JL, Briddon SJ, Kellam B, Hill SJ (2012) Fragment screening at adenosine-A(3) receptors in living cells using a fluorescence-based binding assay. Chem Biol 19(9): 1105-1115

33. Vernall AJ, Stoddart LA, Briddon SJ, Ng HW, Laughton CA, Doughty SW, Hill SJ, Kellam B (2013) Conversion of a nonselective adenosine receptor antagonist into A3-selective high affinity fluorescent probes using peptide-based linkers. Org Biomol Chem 11(34):5673-5682. https://doi.org/10.1039/c3ob41221k

34. Vernall AJ, Stoddart LA, Briddon SJ, Hill SJ, Kellam B (2012) Highly potent and selective fluorescent antagonists of the human adenosine a(3) receptor based on the 1,2,4-triazolo 4,3-a quinoxalin-1-one scaffold. J Med Chem 55(4):1771-1782. https:// doi.org/10.1021/jm201722y

35. Muller CE, Diekmann M, Thorand M, Ozola V (2002) [(3)H]8Ethyl-4-methyl-2-phenyl-(8R)-4,5,7,8-tetrahydro-1H-imidazo[2,1i]-purin-5 -one ([(3)H]PSB-11), a novel high-affinity antagonist radioligand for human $\mathrm{A}(3)$ adenosine receptors. Bioorg Med Chem Lett 12(3):501-503. https://doi.org/10.1016/s0960$894 \mathrm{x}(01) 00785-5$

36. Priego EM, von Frijtag Drabbe Kuenzel J, AP IJ, Camarasa MJ, Perez-Perez MJ (2002) Pyrido[2,1-f]purine-2,4-dione derivatives as a novel class of highly potent human A(3) adenosine receptor antagonists. J Med Chem 45(16):3337-3344. https://doi.org/10.1021/ jm0208469

37. Smith PK, Krohn RI, Hermanson GT, Mallia AK, Gartner FH, Provenzano MD, Fujimoto EK, Goeke NM, Olson BJ, Klenk DC (1985) Measurement of protein using bicinchoninic acid. Anal Biochem 150(1):76-85. https://doi.org/10.1016/0003-2697(85) 90442-7
38. Stoddart LA, Johnstone EK, Wheal AJ, Goulding J, Robers MB, Machleidt T, Wood KV, Hill SJ, Pfleger KD (2015) Application of BRET to monitor ligand binding to GPCRs. Nat Methods 12(7): 661-663. https://doi.org/10.1038/nmeth.3398

39. Baker JG, Middleton R, Adams L, May LT, Briddon SJ, Kellam B, Hill SJ (2010) Influence of fluorophore and linker composition on the pharmacology of fluorescent adenosine A(1) receptor ligands. Br J Pharmacol 159(4):772-786. https://doi.org/10.1111/j.14765381.2009.00488.x

40. Daval SB, Valant C, Bonnet D, Kellenberger E, Hibert M, Galzi JL, Ilien B (2012) Fluorescent derivatives of AC-42 to probe bitopic orthosteric/allosteric binding mechanisms on muscarinic M1 receptors. J Med Chem 55(5):2125-2143. https://doi.org/10.1021/ jm201348t

41. Sykes DA, Parry C, Reilly J, Wright P, Fairhurst RA, Charlton SJ (2014) Observed drug-receptor association rates are governed by membrane affinity: the importance of establishing "micro-pharmacokinetic/pharmacodynamic relationships" at the beta2adrenoceptor. Mol Pharmacol 85(4):608-617. https://doi.org/10. 1124/mol.113.090209

42. Vauquelin G, Charlton SJ (2010) Long-lasting target binding and rebinding as mechanisms to prolong in vivo drug action. Br J Pharmacol 161(3):488-508. https://doi.org/10.1111/j.1476-5381. 2010.00936.x

43. Nederpelt I, Georgi V, Schiele F, Nowak-Reppel K, FernandezMontalvan AE, AP IJ, Heitman LH (2016) Characterization of 12 GnRH peptide agonists - a kinetic perspective. Br J Pharmacol 173(1):128-141. https://doi.org/10.1111/bph.13342

44. Vanderheyden PML, Benachour N (2017) Influence of the cellular environment on ligand binding kinetics at membrane-bound targets. Bioorg Med Chem Lett 27(16):3621-3628. https://doi.org/10.1016/ j.bmcl.2017.06.051

45. McRobb FM, Negri A, Beuming T, Sherman W (2016) Molecular dynamics techniques for modeling $\mathrm{G}$ protein-coupled receptors. Curr Opin Pharmacol 30:69-75. https://doi.org/10.1016/j.coph. 2016.07.001

46. Packeu A, De Backer JP, Van Liefde I, Vanderheyden PM, Vauquelin G (2008) Antagonist-radioligand binding to D2Lreceptors in intact cells. Biochem Pharmacol 75(11):2192-2203. https://doi.org/10.1016/j.bcp.2008.03.001

47. Treherne JM, Young JM (1988) Temperature-dependence of the kinetics of the binding of [3H]-(+)-N-methyl-4methyldiphenhydramine to the histamine H1-receptor: comparison with the kinetics of [3H]-mepyramine. Br J Pharmacol 94(3):811822. https://doi.org/10.1111/j.1476-5381.1988.tb11592.x

48. Sakai S (1991) Effect of hormones on dissociation of prolactin from the rabbit mammary gland prolactin receptor. Biochem J 279(2): 461-465. https://doi.org/10.1042/bj2790461

49. Vernall AJ, Hill SJ, Kellam B (2014) The evolving small-molecule fluorescent-conjugate toolbox for class A GPCRs. Br J Pharmacol 171(5):1073-1084. https://doi.org/10.1111/bph.12265

Publisher's note Springer Nature remains neutral with regard to jurisdictional claims in published maps and institutional affiliations. 